\title{
Effects of apple vinegar addition on aerobic deterioration of fermented high moisture maize using infrared thermography as an indicator
}

\author{
Aylin AGMA OKUR ${ }^{1, *}$, Kerem GOZLUKLU ${ }^{1}$, Ersen OKUR ${ }^{2}$, Berrin OKUYUCU ${ }^{1}$, FisunKOC ${ }^{1}$, and Mehmet Le- \\ vent OZDUVEN 1 \\ 1 Tekirdag Namik Kemal University, Agricultural Faculty, Dept. of Animal Science, 59030 Tekirdag, Turkey \\ 2 Tekirdag Namik Kemal University, Agricultural Faculty, Dept. of Biosystem Engineering, 59030 Tekirdag, \\ Turkey \\ * Correspondence: aagma@nku.edu.tr
}

\begin{abstract}
This study was carried out to determine the effects of apple vinegar and sodium diacetate addition on the aerobic stability of fermented high moisture maize grain (HMM) silage after opening. In the study, the effect of three different levels $(0,0.5,1.0 \%)$ of apple vinegar (AV) and sodium diacetate (SDA) supplementation to fermented HMM at two different storage conditions $\left(27-29^{\circ} \mathrm{C}\right.$, $48 \%$ Humidity; $35-37^{\circ} \mathrm{C}, 26 \%$ Humidity) were investigated. The material of the study was fermented rolled maize grain with $62 \%$ moisture content stored for about 120 days. Silage samples were subjected to aerobic stability test with 3 replicates for each treatment group. Wendee and microbiological analyses were made at 0, 2, 4, 7, and 12 days. Meanwhile, samples were displayed in the T200 IR brand thermal camera. According to the thermogram results, $1 \%$ SDA addition positively affected HMM silages at the second and fourth days of aerobic stability at both storage conditions $(p<0.05)$. Aerobic stability and infrared thermography analysis indicated that $1 \% \mathrm{AV}, 0.5 \%$, and $1 \%$ SDA additions to HMM silages had promising effects. Due to our results, we concluded that thermal camera images might be used as an alternative quality indicator for silages in laboratory conditions.
\end{abstract}

Keywords: apple vinegar; sodium diacetate; high moisture maize grain; aerobic stability; infrared thermography

\section{Introduction}

Conservation of forage and cereal grains as silage is very important, common way for ruminant nutrition in the worldwide [1,2]. The silage process might be divided in four stages: (1) the aerobic stage in the silo immediately after harvest, (2) the fermentation stage, (3) the stable storage stage in the silo, and (4) the feed-out stage when the silo face is opened and exposed to air. Producing high-quality silage, besides avoiding dry matter losses as much as possible, is a challenge and can occur during entire silage process [3].

High moisture maize grain (HMM) is an indispensable part of the total mixed ration (TMR), especially in dairy cattle diets. TMR may comprise 18-20\% HMM. However, the high moisture and starch contents of HMM poses a significant risk in terms of its susceptibility to aerobic degradation during the feeding period [4-8]. However, to reduce the labor in field conditions, ensilaged HMM amount that is taken from the silo would be increased to meet the animals' requirements for 5-7 days, not daily. Also, sometimes the ensilaged HMM is transferred from one farm to another to meet their needs. These situations lead to undesirable consequences in terms of aerobic deterioration. The objective of the study was to improve the aerobic stability of HMM silage by using additives that might be easily prepared and applied. Besides, to reveal the appropriate usage dosages and effects of the additives against the mentioned challenges. 
A wide variety of silage additives have been used to preserve silage for decades. Apple vinegar and sodium diacetate can be identified as chemical additive groups which contains acids and their salts. Previous researches established that sodium diacetate as an effective silage additive [9]. Apple vinegar (AV) consists of mainly acetic acid and used as a natural food preserver for its antibacterial and antioxidant activities that attributed to its organic acid content [10]. Besides, AV might be produced easily at home or farm conditions as an advantage.

The primary cause of silage quality deterioration is respiration. Even if ensiled material is not exposed to oxygen during the production, fermentation and stable period, however when the silo is opened, it is unavoidable that conditions turn to the aerobic stage with air entering the silo [11-13]. During the decomposition process, the dry matter breaks down into $\mathrm{H} 2 \mathrm{O}$ and $\mathrm{CO} 2$ with a release of heat [14]. Aerobic deterioration resulted from activity of aerobic microorganisms such as yeasts and moulds, using water-soluble carbohydrates and fermentation products, resulting with $\mathrm{pH}$ value and heat rising, dry matter loss, decrease in protein and cellulose digestibilities and energy release [11, 15]. In addition, growing moulds may produce mycotoxins, which threaten the health of humans and animals $[16,17]$.

Silage temperature is the proof of good silage management and subsequent handling. If it exceeds $20^{\circ} \mathrm{C}$ even in the summer conditions, it would indicate that silage is not consumable for dairy cattle. Gálik et al. [13] also stated that the self-heating of maize silage to $30^{\circ} \mathrm{C}$ increases the nutrition losses caused by anaerobic fermentation of silage by $1.7 \%$ of dry matter per day. It would be useful to monitor heat differences and detect abnormalities in its early stages. Thermal camera imaging might be used to serve this purpose.

Infrared thermal camera imaging is an objective, non-invasive quality evaluation tool to assess inflammatory reactions, early detections of mastitis, ovarium cycles, foot pathologies in ruminants, equines and poultry, grain quality, deterioration of feed and silage [18-22].

This study aims to evaluate the effects of apple vinegar and sodium diacetate addition on aerobic stability of high moisture fermented grain maize silage and also to reveal the changes of silage quality at different storage conditions by using temperature data logger and thermal camera images.

\section{Materials and Methods}

Silage material

High moisture (62\%) maize grain crushed and fermented in plastic sausage silo for approximately 120 days was used as the research material. At the end of the fermentation process, approximately $40 \mathrm{~kg}$ silage sample was brought to the laboratory and a sample was taken from this freshly opened material to establish the beginning material and was analysed. The fermented high moisture maize samples were then divided into 12 treatment groups with 3 replicates in each. Treatment groups consist of two different supplements (apple vinegar, sodium diacetate) with three different levels $(0,0.5,1 \%)$ and stored at two different storage conditions (room, incubator). For each treatment group, $1000 \mathrm{gr}$ material was weighed, put the plastic bags. Then additives were sprayed on the silage material and mixed for homogeneity. In the control groups, $20 \mathrm{ml}$ purified water were added as an equivalent dose to the treatment groups. After additives supplemented, silage samples were stored for 12 days to evaluate the aerobic stability changes at $27-29^{\circ} \mathrm{C}$ (48\% humidity) and $35-37^{\circ} \mathrm{C}(26 \%$ humidity).

Laboratory Analysis

Dry matter (DM), pH, lactic acid (LA), water soluble carbohydrate (WSC), ammonianitrogen (NH3-N), lactic acid bacteria, yeast and mould counts analysis were evaluated at 0th, 2nd, 4 th, 7 th and 12th days of aerobic stability in silage samples. Temperature changes in the storage ambient and inside the silage samples have been recorded by data logger devices (Hobo pendant) every 30 minutes during the experiment period. 
Chemical analyses were performed on triplicate samples. DM was determined by oven drying for $48 \mathrm{~h}$ at $60^{\circ} \mathrm{C}$. The $\mathrm{pH}$ in fresh material and silage samples was measured according to the British standard method [23]. The ammonia nitrogen (NH3-N) content of silages was determined, according to Jackson et al. [23]. The WSC content of silages was determined by spectrophotometer (Shimadzu UV-1201, Kyoto, Japan); after reaction with antron reagent [24]. Lactic acid (LA) was determined by the spectrophotometric method [25]. Microbiological evaluation included enumeration of lactobacilli on pour-plate Rogosa agar (Oxoid CM627, Oxoid, Basingstoke, UK). Yeast and moulds were determined by pour-plating in malt extract agar (Oxoid CM59) that had been acidified, after autoclaving, by the addition of $85 \% \mathrm{LA}$ at a concentration of $0.5 \% \mathrm{vol} / \mathrm{vol}$. Plates were incubated aerobically at $32^{\circ} \mathrm{C}$ for $48-72 \mathrm{~h}$.

Infrared Thermal Camera Imaging

Thermal camera imaging was recorded by using Fluke Ti9 IR (IR Sensor Size: 160x120 Focal Plane Array) thermal camera from 1 meter distance with 20x30cm surface size (with two replicates from each sample; $n=24)$. Thermography images were taken in the laboratory conditions (ambient temperature: $22^{\circ} \mathrm{C}$ ) without direct sunlight and air velocity. The average, minimum, and maximum temperatures of the silage surface were calculated using SmartView ${ }^{\circledR}$ software program in which each pixel of the image was allocated to one temperature value.

\section{Statistical Analysis}

The research was conducted according to the $2 \times 2 \times 3$ factorial trial design. To reveal the effects of treatment and temperature, the data were evaluated according to the variance analysis technique. If the difference between groups was found to be significant, Duncan's range test was applied [26]. The applied mathematical model was as follows (Eq. 1);

$$
Y i j k=\mu+A i+B j+C k+(A B) i j+(A C) i k+(B C) j k+(A B C) i j k+e i j k l
$$

Yijk : observation applying the ith supplement with jth inclusion level and stored at kth temperature

$\mu \quad$ : overall average

Ai : effect of ith supplement

$\mathrm{Bj} \quad$ : effect of $\mathrm{jth}$ inclusion level of supplement

Ck : effect of kth storage temperature

(AB)ij: interaction effect of ith supplement $x$ jth inclusion level

(AC)ik : interaction effect of ith supplement $x$ kth storage temperature

$(B C) j k$ : interaction effect of jth inclusion level $x \mathrm{kth}$ storage temperature

$(\mathrm{ABC}) \mathrm{ijk} \quad$ : interaction effect of ith supplement $\mathrm{x}$ jth inclusion level $\mathrm{x}$ kth storage temperature

eijkl : error associated with each observation

\section{Results and Discussion}

This section may be divided by subheadings. It should provide a concise and precise description of the experimental results, their interpretation, as well as the experimental conclusions that can be drawn.

In Table 1, the analysis results of the beginning material of fermented maize silage are given. Mould has not been detected in the initial materials. As a result of thermal camera footage carried out on day zero of aerobic stability, the average temperature of fermented maize silage was $30.62^{\circ} \mathrm{C}$, while the background temperature was $22^{\circ} \mathrm{C}$.

Demirel et al. [27] stated that there is an inverse relationship between the DM and $\mathrm{pH}$ levels of the raw material to be ensilaged. Their results showed that the $\mathrm{pH}$ value of corn silage (with $23.48 \% \mathrm{DM}$ ) harvested during the milking phase was 4.15 . The $\mathrm{pH}$ measured after opening the HMM silage and found to be low (as 3.900). These results might be evaluated as a harmonious result with Demirel et al. [27]. 


\subsection{2 nd day of aerobic deterioration}

Second-day aerobic stability results of HMM silages are presented in Table 2. In the LAB count results, the lowest value was observed in the groups that were added $0.5 \%$ SDA and stored in the incubator, and the highest value was observed in the groups that were added $1 \% \mathrm{AV}$ and stored at room temperature. Also, significant reductions in LAB numbers were observed in all silage samples stored in the incubator $\left(35-37^{\circ} \mathrm{C}, 26 \%\right.$ humidity; $\mathrm{p}<0.001)$. High temperatures with decrease in humidity might be responsible for the change in LAB counts. However, no yeast could be detected in groups with $0 \%$ and $1 \% \mathrm{AV}$ and $1 \%$ SDA supplemented and stored in the room conditions $(\mathrm{p}<0.001)$. According to the mould count results, the highest value was found in SDA control group that stored in the incubator conditions with $3.310 \log 10 \mathrm{cfu} / \mathrm{g}$, while the lowest value was 2.220 $\log 10 \mathrm{cfu} / \mathrm{g}$ in $0.5 \%$ vinegar added and stored under room conditions $(\mathrm{p}<0.001)$.

\subsection{4th day of aerobic deterioration}

Aerobic stability analysis results of HMM silage on fourth day of storage were given at Table 3. LAB counts were intended to be lower at SDA added groups and also lower at groups stored at $35-37^{\circ} \mathrm{C}(\mathrm{p}<0.001)$. In addition, the highest LA level was observed at $0.5 \%$ SDA supplemented and stored at room conditions $\left(27-29^{\circ} \mathrm{C} ; 48 \%\right.$ Humidity; $\left.\mathrm{p}<0.05\right)$. In addition lowest yeast counts were observed at 0.5 and $1 \%$ SDA added and stored at high temperatures $(\mathrm{p}<0.001)$. However, WSC levels were not affected by additive sources $(p>0.05)$. In order to avoid deterioration of the ensilaged material, there must be LAB in the silage and also sufficient amount of WSC. So, LAB can produce LA required for silage fermentation by using WSC in the medium [28]. However, Alçiçek and Özkan [29] reported that LA content should not be higher than $2 \%$ for the good silage quality.

Fermentation properties of silages are also effective on aerobic deterioration. Unused sugars and high levels of LA in the silage reduce aerobic stability. Some yeasts and moulds might cause $\mathrm{CO} 2$ production in silages by using the remaining sugars and LA as nutrients. As a result, an increase occurs in ambient $\mathrm{pH}$ and temperature [30]. The data obtained from the study support the previous research results [31-33].

\subsection{7th day of aerobic deterioration}

The effects of additives on HMM silage on the seventh day of aerobic stability are presented in Table 4. When $\mathrm{pH}, \mathrm{NH} 3-\mathrm{N}$, WSC analysis results, LAB and yeast numbers are evaluated, it has seen that the highest values belong to the SDA control group under room conditions $\left(27-29^{\circ} \mathrm{C} ; 48 \%\right.$ Humidity; $\left.\mathrm{p}<0.001\right)$. However, the highest LA value $(13.740 \mathrm{~g} / \mathrm{kg} \mathrm{DM})$ was found in silages stored in the incubator with $0.5 \% \mathrm{SDA}$, while the lowest LA $(1.147 \mathrm{~g} / \mathrm{kg})$ was observed in silages stored in room conditions with $1 \% \mathrm{AV}$ addition $(\mathrm{p}<0.001)$. The effects of silage additive, addition level, storage temperature, their double and triple interactions on $\mathrm{pH}, \mathrm{NH}-\mathrm{N}, \mathrm{LA}, \mathrm{WSC}$ and LAB values were found statistically different $(\mathrm{p}<0.001)$.

Pahlow et al. [16] reported that the number of yeast in high-moisture maize silages was 3-5 $\log 10 \mathrm{cfu} / \mathrm{g}$ and that high yeast count reduced aerobic stability, especially at high temperatures. Teller et al. [34] stated that physical damage to the grain might cause substrate formation for microorganisms and might cause the high yeast content in high-moisture maize silages. Considering the results of the research, the high yeast content in the control group particularly at high temperatures supports previous studies on this subject. Besides, there was a decrease in the yeast and LAB numbers of the silages stored in the incubator. In addition, mould counts were found to be zero in silages stored in incubator conditions for all additives, and additional levels $(\mathrm{p}<0.001)$. In the study, silage samples stored at $35-37^{\circ} \mathrm{C}$ had relatively low humidity $(26 \%)$. That might have affected microbial growth negatively. However, $1 \%$ SDA addition has been found effective in both room and incubator conditions on LAB and Yeast counts. 


\subsection{2th day of aerobic deterioration}

The twelfth day analysis results of aerobic stability are given in Table 5. According to the $\mathrm{pH}$ results, it was observed that the lowest values were found in silages stored at high temperatures and the effect of storage temperatures was statistically significant $(p<0.001)$. Similarly, a decrease was observed in NH3-N values under high temperature storage conditions $(\mathrm{p}<0.01)$. However, the NH3-N value was found to be lower in the group containing $1 \%$ SDA and stored in room conditions $(\mathrm{p}<0.01)$.

In addition, WSC contents were found lower in all groups stored at room conditions, too. However, one of the lowest values were detected at $0.5 \% \mathrm{AV}$ added and incubator stored group. McDonald [14] has been stated that WSC are the most important energy source used by lactic acid bacteria. Some researchers observed an increase in the amount of WSC due to increasing SDA supplementation. Researchers attributed this increase to the antifungal properties of additives [35-37]. They prevent growth of unwanted microorganisms and caused reduction of DM and nutrition losses. In the study all parameters (additives, addition ratios and storage conditions) were revealed significant effects on WSC $(\mathrm{p}<0.001)$.

LA levels were demonstrated an increase at higher storage temperatures except for $1.0 \%$ SDA added groups. Besides, the highest value $(11.407 \mathrm{~g} / \mathrm{kg})$ was determined in the $1 \% \mathrm{AV}$ added groups. Reeves et al. [38] reported that the amount of LA in dry matter of maize silage varied between $1.58 \%$ and $8.57 \%$. In addition, Deswysen et al. [39] reported that the amount of lactic acid on dry matter in maize silage was $6.31 \%$, while Phillip and Hidalgo [40] reported that it was 5\%. In the present study, LA levels ranged between $0.881-1.469 \%$ on the second day, and $0.030-1.141 \%$ on the twelfth day of aerobic stability (Table 2, Table 5).

According to the results of the twelfth day of aerobic stability, there was an increase in LAB counts of silage samples stored in the incubator compared to those in the chamber, but a decrease in yeast count was observed (except vinegar control and $0.5 \%$ SDA supplemented groups) ( $\mathrm{p}<0.001)$. In addition to these results, mould counts were found to be 0 in all treatment groups on the 12th day of aerobic stability.

\subsection{Thermal camera imaging results of aerobic stability}

Temperature data obtained from dataloggers for twelve days were summarized in Figure 1, Figure 2, Figure 3, and Figure 4. The temperatures of sensor data and thermal camera images in the study showed compatible results with each other. The finding was parallel with two field studies [41, 42].

Mean, maximum, minimum and standard deviation values of temperature measurements of aerobic stability period were determined by thermal camera and results are presented in Table 6, Table 7, Table 8, and Table 9. Arithmetic means was subsequently created on the basis of all values. Data logger records at the time of thermograms taken were also given at the tables. Additionally, one of the thermograms captured from each treatment ( $n=12$; same samples during the experiment) were shown at Figure 5, 6, 7, and 8. They might help to visualize the heat differences in the silage samples.

On the 2nd and 4th day of aerobic stability, the lowest temperature values were observed in the 1\% SDA added HMM silages at both storage temperatures (Table 6, Table 7 ). In the thermal camera measurements conducted on the 7th day of storage, the lowest temperature values were observed in the SDA control group kept under room conditions (Table 8). Thermograms of the 12th day of aerobic stability showed that the lowest values were found in the groups that AV added and kept under room conditions (Table 9). These results supported the importance of storage conditions and additives on quality properties of silages even after opening $(\mathrm{p}<0.01)$.

Thermal camera imaging results of aerobic stability approved that the temperature of silage samples stored in $35-37^{\circ} \mathrm{C}$ was higher compared to the stored at $27-29^{\circ} \mathrm{C}$. However, when the temperature differences between the silages and the storage environment 
are considered, it is seen that the temperature differences increase in the room conditions (27-29ㄷ $\mathrm{C}$; $4 \%$ humidity), heat rises in the samples and therefore deterioration occurs in stored silages. Similarly Kaya and Polat [43] reported that more than 2 degrees celsius of the temperature difference between the ambient and silage may indicate deterioration. Koc et al. [44] also indicated that heat differences are major signs of deterioration.

Heat differences in maize silages stored at $27-29^{\circ} \mathrm{C}$, started to increase at day 4 . However, on day 7 differences had maximized and started to decline at day 12 . Due to this increase on seventh day, $\mathrm{pH}$ values, yeast and mould counts were found higher for all treatments in room conditions. Similarly Junga and Trávníček [12] have found a connection between infrared thermography images with chemical, and microbial analyse results in the field conditions. Samples from surfaces with higher temperature have resulted with increase in $\mathrm{pH}$ values, mould and yeast counts. Santos et al. [17] indicated that feeding silages with high concentrations of yeasts from aerobic spoilage is often implicated as a cause of poor animal performance on dairy animals.

Borreani and Tabacco [45] evaluated the temperature at 11 locations on 54 silos and correlated the temperature with chemical composition and microbial count. They also concluded that temperature is linked to microbial activity and might be an important indicator of the early stages of aerobic degradation.

Addah et al. [20] used infrared thermal imaging technique to assess the heating of barley silages stored in large cylindrical bag silos could serve as a simple and rapid method of directly measuring and visualizing heat distribution over the feed-out face of silos in real-time.

Alsaaod et al. [22] reported that environmental factors such as airflow, environment temperature, humidity, sunlight and motion could be affected the thermograms. Environment conditions preferred to be in the neutral zone temperature, without direct sunlight and detectable airflow. In addition, infrared thermal imaging technique does not need light or shadow to capture frame accurately [46].

Researchers suggested that infrared thermography might be used for quick temperature detection of silo surface, of silage layers and also might be a practical method for assessing the aerobic stability of silages on field and laboratory conditions [12, 20, 42, 47]. According to the results of study, thermal camera imaging technique might be used to detect temperature differences and to reveal deterioration in the silage.

\section{Conclusions}

Fermented high moisture maize grain (HMM) is an important part of the TMR for dairy cattle rations with $18-20 \%$ inclusion levels. However, low dry matter and high starch contents of HMM increases the aerobic deterioration risks during feeding period. The objective of the study was to improve and reveal aerobic stability duration after opening HMM silage by easily prepared and supplemented additives.

In the light of the study results, it was seen that the silage additives and their usage levels had a positive effect on dry matter, NH3-N, LA production, WSC amount, LAB and yeast counts. In addition to these results, it was observed that the storage temperature had a significant effect on $\mathrm{pH}, \mathrm{NH}-\mathrm{N}$, LA production, WSC, the numbers of LAB and yeast. The additive usage (\%) and their effects on aerobic stability parameters were not in line in the study. Differences in this regard may be due to the chemical, physical and microbiological properties of the beginning material.

When the thermal camera images were evaluated, the temperature differences between silage and storage environment might be able to become more visible. Due to increase in temperature differences at room conditions in the fourth day of aerobic stability, deterioration observed in the HMM silage. The similarity and relation between these results and microbial composition results is also noteworthy. The results support that the infrared thermography method might be an effective tool in the early detection of silage deterioration in laboratory conditions. 
It was concluded that supplementing different doses of apple vinegar and sodium diacetate to HMM silages after silo opening improved aerobic stability, but further studies needed to determine effective dosages of apple vinegar on field conditions and also needed to support with in vivo studies.

Supplementary Materials: The following are available online at www.mdpi.com/xxx/s1, Figure S1: title, Table S1: title.

Author Contributions: Conceptualization, F.K., M.L.O and A.A.O.; Methodology, F.K., M.L.O and A.A.O.; Software, A.A.O.; Validation, A.A.O., B.O. and E.O.; Formal Analysis, E.O., B.O., K.G., F.K. and A.A.O.; Investigation, A.A.O, K.G. and E.O.; Resources, F.K., M.L.O., B.O., E.O. and K.G.; Data Curation, A.A.O.; Writing - Original Draft Preparation, A.A.O.; Writing - Review \& Editing, A.A.O. and F.K.; Visualization, A.A.O., E.O..; Supervision, M.L.O and F.K..; Project Administration, A.A.O. All authors have read and agreed to the published version of the manuscript.

Funding: This research did not receive any specific grant from funding agencies in the public, commercial, or not-for-profit sectors.

Institutional Review Board Statement: Not applicable.

Informed Consent Statement: Not applicable.

Data Availability Statement: The data that support the findings of this study are available from the corresponding author, [author initials], upon reasonable request.

Acknowledgments: The authors are grateful to the technical support of the Agricultural Faculty, Tekirdag Namik Kemal University, Turkey.

Conflicts of Interest: The authors declare no conflict of interest.

\section{References}

1. Carvalho, B.F.; Sales, G.F.C.; Schwan, R.F.; Ávila, C.L.S. Criteria for lactic acid bacteria screening to enhance silage quality. Journal of Applied Microbiology 2020, 130, 341-355, doi:10.1111/jam.14833.

2. Guan, H.; Shuai, Y.; Yan, Y.; Ran, Q.; Wang, X.; Li, D.; Cai, Y.; Zhang, X. Microbial community and fermentation dynamics of corn silage prepared with heat-resistant lactic acid bacteria in a hot environment. Microorganisms 2020, 8, 719, 18 pages, doi:10.3390/microorganisms8050719.

3. Borreani, G.; Tabacco, E.; Schmidt, R.J.; Holmes, B.J.; Muck, R.E. Silage review: Factors affecting dry matter and quality losses in silages. J Dairy Sci. 2018, 101, 3952-3979, doi:10.3168/jds.2017-13837.

4. Wardynski, F.A.; Rust, S.R.; Yokoyama, M.T. Effect of microbial inoculation of high-moisture corn on fermentation characteristics, aerobic stability, and cattle performance. J Anim Sci. 1993, 71, 2246-2252, doi:10.2527/1993.7182246x.

5. Dawson, T.E.; Rust, S.R.; Yokoyama, M.T. Improved fermentation and aerobic stability of ensiled, high moisture corn with the use of Propionibacterium acidipropionici. J Dairy Sci. 1998, 81, 1015-1021, doi:10.3168/jds.S0022-0302(98)75663-2.

6. Taylor, C.C.; Kung L., Jr. The effect of Lactobacillus buchneri 40788 on the fermentation and aerobic stability of high moisture corn in laboratory silos. J Dairy Sci. 2002, 85, 1526-1532, doi:10.3168/jds.S0022-0302(02)74222-7.

7. Canibe, N.; Kristensen, N.B.; Jensen, B.B.; Vils, E. Impact of silage additives on aerobic stability and characteristics of highmoisture maize during exposure to air, and on fermented liquid feed. Journal of Applied Microbiology 2014, 116, 747-760, doi:10.1111/jam.12427.

8. Özelçam, H.; Daşıkan, H. Effect of carvacrol adding to corn silage on the aerobic stability. Ege Üniversitesi Ziraat Fakültesi Derg. 2017, 54, 409-412, doi:10.20289-zfdergi.386442-414463.

9. Muck, R.E.; Nadeau, E.M.G.; McAllister, T.A.; Contreras-Govea, F.E.; Santos, M.C.; Kung, L., Jr. Silage review: Recent advances and future uses of silage additives. Journal of Dairy Science 2018, 101, 3980-4000, doi:10.3168/jds.2017-13839.

10. Ousaaid, D.; Imtara, H.; Laaroussi, H.; Lyoussi, B.; Elarabi, I. An investigation of moroccan vinegars: Their physicochemical properties and antioxidant and antibacterial activities. Journal of Food Quality 2021, 6618444, 8 pages, doi:10.1155/2021/6618444.

11. Filya, I.; Sucu, E.; Karabulut, A. The effect of Propionibacterium acidipropionici, with or without Lactobacillus plantarum, on the fermentation and aerobic stability of wheat, sorghum and maize silages. J Appl Microbiol. 2004, 97, 818-826, doi:10.1111/j.13652672.2004.02367.x.

12. Junga, P.; Trávníček, P. Surface temperature of the exposed silo face as quick indicator of the decomposition process of maize silage. Journal of Central European Agriculture 2015, 16, 76-91, doi:10.5513/JCEA01/16.1.1544.

13. Gálik, R.; Bod’o, Š.; Staroňová, L. Using modern diagnostic methods for technological discipline assessment of maize silage. Acta Technologica Agriculturae 2, Nitra, Slovaca Universitas Agriculturae Nitriae 2016, 39-42, doi:10.1515/ata-2016-0009. 
14. McDonald, P.; Henderson, A.R.; Heron, S.J.E. The Biochemistry of Silage, 2nd ed.; Chalcombe Publications, Marlow, UK, 1991, pp. 340.

15. Muck, R.E.; Pitt, R.E.; Leibensperger, R.Y. A model of aerobic fungal growth in silage. 1. Microbial characteristics. Grass and Forage Science 1991, 46, 283-299, doi:10.1111/j.1365-2494.1991.tb02234.x.

16. Pahlow, G.; Muck, R.E.; Driehuis, F.; Oude Elferink, S.J.W.H.; Spoelstra, S.F. Chapter 2: Microbiology of ensiling. In: Silage Science and Technology, 42, 31-93. Buxton, D.R.; Muck, R.E.; Harrison, J.H. (eds), American Society of Agronomy, Madison, WI, USA, 2003, doi:10.2134/agronmonogr42.c2.

17. Santos, M.C.; Lock, A.L.; Mechor, G.D.; Kung, L., Jr. Effects of a spoilage yeast from silage on in vitro ruminal fermentation. J Dairy Sci. 2014, 98, 2603-2610, doi:10.3168/jds.2014-8683.

18. Hovinen, M.; Siivonen, J.; Taponen, S.; Hänninen, L.; Pastell, M.; Aisla, A.-M.; Pyörälä, S. Detection of clinical mastitis with the help of a thermal camera. J Dairy Sci. 2008, 91, 4592-4598, doi:10.3168/jds.2008-1218.

19. Gowen, A.A.; Tiwari, B.K.; Cullen, P.J.; McDonnell, K.; O’Donnell, C.P. Applications of thermal imaging in food quality and safety assessment. Trends in Food Science \& Technology 2010, 21, 190-200, doi:10.1016/j.tifs.2009.12.002.

20. Addah, W.; Baah, J.; Okine E.K.; McAllister T.A. Use of thermal imaging and the in situ technique to assess the impact of an inoculant with feruloyl esterase activity on the aerobic stability and digestibility of barley silage. Can J Anim Sci. 2012, 92, 381394, doi:10.4141/CJAS2012-016.

21. Talukder, S.; Kerrisk, K.L.; Ingenhoff, L.; Garcia, S.C.; Celi P. Can digital infrared thermography help with prediction of ovulation in a pasture-based dairy. In Conference Proceedings, Current Topics in Dairy Production, The University of Sydney, Kiam, Australia, 2013, $1-4$. (https://www.researchgate.net/publication/280734946_Can_digital_infrared_thermography_help_with_prediction_of_ovulati on_in_a_pasture-based_dairy_system). [Accessed 2020 August 18].

22. Alsaaod, M.; Schaefer, A.L.; Büscher, W.; Steiner, A. The role of infrared thermography as a non-invasive tool for the detection of lameness in cattle. Sensors 2015, 15, 14513-14525, doi: 10.3390/s150614513.

23. Jackson, E.; Farrington, D.S.; Henderson, K. The analysis of agricultural materials: a manual of the analytical methods used by the Agricultural Development and Advisory Service (ADAS). Reference Book: 427, Analytical Chemists' Publications, London, 1986, pp. 248.

24. Thomas, T.A. An automated procedure for the determination of soluble carboydrates in herbage. J Sci Fd Agric. 1977, 28, 639642, doi:10.1002/jsfa.2740280711.

25. Koc, F.; Coskuntuna, L. The comparison of the two different methods on the determination of organic acids in silage fodders. Journal of Animal Production 2003, 44, 37-46 (https://dergipark.org.tr/en/pub/hayuretim/issue/7626/99907).

26. Statistica. Statistica for the Windows Operating System. Stat Soft, Inc., Tulsa, OK, USA, 1999.

27. Demirel, M.; Cengiz, F.; Çelik, S.; Erdoğan, S. A study on degradability in rumen and silage quality of mixture of corn and hungarian vetch grown in Van ecological conditions. Yuzuncu Yil University Journal of Agricultural Sciences 2001, 11, 69-78 (https://dergipark.org.tr/en/pub/yyutbd/issue/22001/236224).

28. Filya, I. The effect of Lactobacillus buchneri and Lactobacillus plantarum on the fermentation, aerobic stability, and ruminal degradability of low dry matter corn and sorghum silages. J Dairy Sci. 2003, 86, 3575-3581, doi:10.3168/jds.S0022-0302(03)739630 .

29. Alçiçek, A.; Özkan, K. Silo yemlerinde fiziksel ve kimyasal yöntemlerle silaj kalitesinin saptanması [Determination of silage quality in silo feeds by physical and chemical methods] (in Turkish). Türkiye I. Silaj Kongresi, Bursa, Turkey, 1997, p. $241-246$.

30. Ashbell, G.; Pahlow, G.; Dinter, B.; Weinberg, Z.G. Dynamics of orange peel fermentation during ensilage. Journal of Applied Bacteriology 1987, 63, 275-279, doi: 10.1111/j.1365-2672.1987.tb02703.x.

31. Uriarte-Archundia M.E. (2001). A study of the chemical and microbial changes in whole-plant corn silage during exposure to air: Effects of stage of maturity, packing density, sealing technique, and a biological additive. Ph.D. Thesis. Kansas State University, Manhattan, Kansas, 2001, pp. 110.

32. Koc, F.; Coskuntuna, L.; Ozduven, M.L.; Coskuntuna, A.; Samlı, H.E. The effects of temperature on the silage microbiology and aerobic stability of corn and vetch-grain silages. Acta Agriculturae Scandinavica, Section A-Animal Science 2009, 59, 239-246, doi:10.1080/09064700903490596.

33. Wilkinson, J.M.; Davies, D.R. The aerobic stability of silage: Key finding and recent developments. Grass and Forage Science 2012, 68, 1-19, doi:10.1111/j.1365-2494.2012.00891.x.

34. Teller, R.S.; Schmidt, R.J.; Whitlow, L.W.; Kung, L. Jr. Effect of physical damage to ears of corn before harvest and treatment with various additives on the concentration of mycotoxins, silage fermentation, and aerobic stability of corn silage. J Dairy Sci. 2012, 95, 1428-1436, doi:10.3168/jds.2011-4610.

35. Nadeau, E.M.G.; Buxton, D.R.; Russell, J.R.; Allison, M.J.; Young, J.W. Enzyme, bacterial inoculant, and formic acid effects on silage composition of orchardgrass and alfalfa. J Dairy Sci. 2000, 83, 1487-1502, doi:10.3168/jds.S0022-0302(00)75021-1.

36. Da Silva, T.C.; Smith, M.L.; Barnard, A.M.; Kung, L., Jr. The effect of a chemical additive on the fermentation and aerobic stability of high-moisture corn. J Dairy Sci. 2015, 98, 8904-8912, doi:10.3168/jds.2015-9640. 
37. Yuan, X.; Wen, A.; Desta, S.T.; Wang, J.; Shao, T. Effects of sodium diacetate on the fermentation profile, chemical composition and aerobic stability of alfalfa silage. Asian-Australas J Anim Sci. 2017, 30, 804-810, doi:10.5713/ajas.16.0773.

38. Reeves, J.B., III, Blosser, T.H., Colenbrander, V.F. Near infrared reflectance spectroscopy for analyzing undried silage. J Dairy Sci. 1989, 72, 79-88, doi:10.3168/jds.S0022-0302(89)79082-2.

39. Deswysen, A.G.; Dutilleul, P.; Godfrin, J.P.; Ellis, W.C. Nycterohemeral eating and ruminating patterns in heifers fed grass or corn silage: analysis by finite Fourier transform. Journal of Animal Science 1993, 71, 2739-2747, doi:10.2527/1993.71102739x.

40. Phillip, L.E.; Hidalgo, V. Voluntary feed intake, acid-base balance and partitioning of urinary nitrogen in lambs fed corn silage with added sodium bicarbonate or sodium sesquicarbonate. J Anim Sci. 1989, 67, 2116-2122, doi:10.2527/jas1989.6782116x.

41. Erdoğan, A.; Koç, F. Evaluation of the changes in microbial composition in farm conditions during aerobic stability using thermal camera imaging technique. J Anim Prod. 2020, 61, 9-16, doi:10.29185/hayuretim.538180.

42. Koc, F.; Ozduven, M.L.; Demirci, A.S.; Samli, H.E. Evaluation of the changes in microbial composition of corn silage under farm conditions during aerobic stability using thermal camera imaging technique. KSU J Agric Nat. 2018, 21, 167-174, doi:10.18016/ksudobil.297173.

43. Kaya, Ö.; Polat C. Determination of silage fermentation characteristics and feed value of some corn varieties cultivars as first and second crop in Tekirdag ecological conditions. Journal of Tekirdag Agricultural Faculty 2010, 7, $129-136$ (https://dergipark.org.tr/en/pub/jotaf/issue/19044/201426).

44. Koc, F.; Agma Okur, A.; Okur, E. The effects of sodium diacetate and sodium benzoat addition on the aerobic stability characteristics of high moisture corn grain. Ege Üniv Ziraat Fak Derg. 2020, 57, 289-301, doi:10.20289/zfdergi.611010.

45. Borreani, G.; Tabacco, E. The relationship of silage temperature with the microbiological status of the face of corn silage bunkers. J Dairy Sci. 2010, 93, 2620-2629, doi:10.3168/jds.2009-2919.

46. Zaninelli M., Redaelli V., Tirloni E., Bernardi C., Dell'Orto V., Savoini G. First results of a detection sensor for the monitoring of laying hens reared in a commercial organic egg production farm based on the use of infrared technology. Sensors 2016, 16, 1757, 13 pages, doi:10.3390/s16101757.

47. Unal, O.; Koc, F.; Agma Okur, A.; Okur, E.; Ozduven, M.L. Using thermal imaging camera technique to evaluation of the aerobic stability of corn and wheat silage. Alnteri Journal of Agriculture Sciences 2018, 33, 55-63, doi:10.28955/alinterizbd.362241. 
Table 1. Chemical and microbiological analysis results for the beginning material (day 0)

\begin{tabular}{lc}
\hline Parameters & Analysis Results \\
\hline $\mathrm{pH}$ & 3.900 \\
$\mathrm{DM}, \%$ FM & 62.021 \\
$\mathrm{NH} 3-\mathrm{N}$ g/kg DM & 1.289 \\
$\mathrm{LA}, \mathrm{g} / \mathrm{kg} \mathrm{DM}$ & 9.200 \\
$\mathrm{WSC}, \mathrm{g} / \mathrm{kg} \mathrm{DM}$ & 11.418 \\
$\mathrm{LAB}, \mathrm{cfu} / \mathrm{g} \mathrm{DM}$ & 2.712 \\
Yeast, cfu/g DM & 2.723 \\
Mould, cfu/g DM & 0 \\
\hline${ }^{1}$ DM: Dry matter, FM: Fresh material, NH3-N: Ammonia- nitrogen, LA: Lactic acid, WSC: Water- \\
soluble carbohydrate, LAB. Lactic acid bacteria, cfu: colony forming unit
\end{tabular}


Table 2. Effects of additives and storage conditions on second day of aerobic stability of high moisture maize silage

\begin{tabular}{|c|c|c|c|c|c|c|c|c|c|c|}
\hline Additive & $\begin{array}{c}\text { Usage } \\
\text { \% }\end{array}$ & $\begin{array}{c}\text { Storage } \\
\text { temperature* }\end{array}$ & $\mathrm{pH}$ & $\begin{array}{l}\text { DM } \\
\%\end{array}$ & $\begin{array}{c}\mathrm{NH}_{3}-\mathrm{N} \\
\mathrm{g} / \mathrm{kg} \mathrm{DM}\end{array}$ & $\begin{array}{c}\text { LA } \\
\mathrm{g} / \mathrm{kg} \mathrm{DM}\end{array}$ & $\begin{array}{c}\text { WSC } \\
\text { g/kg DM }\end{array}$ & $\begin{array}{c}\text { LAB } \\
\log _{10} \mathrm{cfu} / \mathrm{g}\end{array}$ & $\begin{array}{c}\text { Yeast } \\
\log _{10} \mathrm{cfu} / \mathrm{g}\end{array}$ & $\begin{array}{c}\text { Mould } \\
\log _{10} \mathrm{cfu} / \mathrm{g}\end{array}$ \\
\hline \multirow{6}{*}{ AV } & \multirow[t]{2}{*}{0} & $27-29^{\circ} \mathrm{C}$ & $3.850 \mathrm{c}$ & $59.550 \mathbf{b}$ & $1.577 \mathbf{a b}$ & 9.760 defg & $9.870 \mathbf{g}$ & $4.303 \mathrm{bc}$ & $0.000 \mathrm{~g}$ & $2.527 \mathbf{f}$ \\
\hline & & $35-37^{\circ} \mathrm{C}$ & $3.900 \mathrm{c}$ & $63.890 \mathbf{a}$ & 1.380 cde & $13.600 \mathrm{ab}$ & $19.857 \mathbf{b}$ & $2.933 \mathrm{e}$ & $4.517 \mathbf{e}$ & 2.847 de \\
\hline & \multirow[t]{2}{*}{0.5} & $27-29^{\circ} \mathrm{C}$ & $3.900 \mathrm{c}$ & $60.550 \mathbf{b}$ & $1.263 \mathrm{e}$ & 9.470 efg & 17.440 de & $4.533 \mathbf{a b}$ & $4.660 \mathrm{~d}$ & $2.220 \mathrm{~h}$ \\
\hline & & $35-37^{\circ} \mathrm{C}$ & $3.900 \mathrm{c}$ & $60.310 \mathbf{b}$ & $1.520 \mathrm{abc}$ & 11.473 bcdef & 15.370 f & $3.180 \mathrm{e}$ & $4.467 \mathbf{e}$ & $3.093 \mathbf{b}$ \\
\hline & \multirow[t]{2}{*}{1.0} & $27-29^{\circ} \mathrm{C}$ & $3.900 \mathrm{c}$ & $61.233 \mathbf{b}$ & $1.570 \mathbf{a b}$ & $8.810 \mathrm{~g}$ & 19.613 bc & $4.610 \mathbf{a}$ & $0.000 \mathrm{~g}$ & $2.363 \mathrm{~g}$ \\
\hline & & $35-37^{\circ} \mathrm{C}$ & $3.900 \mathrm{c}$ & $59.913 \mathbf{b}$ & $1.613 \mathrm{ab}$ & 11.790 bcde & $18.043 \mathrm{~d}$ & $4.053 \mathrm{~cd}$ & $4.250 \mathbf{f}$ & $2.823 \mathrm{e}$ \\
\hline \multirow{6}{*}{ SDA } & \multirow[t]{2}{*}{0} & $27-29^{\circ} \mathrm{C}$ & $3.850 \mathrm{c}$ & $60.140 \mathbf{b}$ & $1.330 \mathrm{de}$ & $9.280 \mathrm{fg}$ & $10.610 \mathbf{g}$ & $4.407 \mathbf{a b}$ & $4.830 \mathrm{c}$ & $2.993 \mathrm{bcd}$ \\
\hline & & $35-37^{\circ} \mathrm{C}$ & $3.900 \mathrm{c}$ & 58.760 c & $1.687 \mathbf{a}$ & $14.690 \mathbf{a}$ & $17.530 \mathrm{~d}$ & $2.920 \mathrm{e}$ & $4.780 \mathrm{c}$ & $3.310 \mathbf{a}$ \\
\hline & \multirow[t]{2}{*}{0.5} & $27-29^{\circ} \mathrm{C}$ & $4.007 \mathrm{~b}$ & $60.673 \mathbf{b}$ & $1.470 \mathrm{bcd}$ & 10.753 cdefg & 18.977 c & $4.460 \mathbf{a b}$ & 4.777 c & $3.030 \mathrm{bc}$ \\
\hline & & $35-37^{\circ} \mathrm{C}$ & $4.010 \mathrm{~b}$ & $59.240 \mathbf{b}$ & $1.447 \mathrm{bcd}$ & $12.287 \mathrm{bc}$ & $16.667 \mathbf{e}$ & $2.227 \mathbf{f}$ & $4.903 \mathbf{b}$ & 2.890 cde \\
\hline & \multirow[t]{2}{*}{1.0} & $27-29^{\circ} \mathrm{C}$ & $4.007 \mathbf{b}$ & $59.587 \mathbf{b}$ & 1.390 cde & 12.047 bcd & $15.420 \mathbf{f}$ & $3.933 \mathrm{~d}$ & $0.000 \mathrm{~g}$ & $3.000 \mathrm{bcd}$ \\
\hline & & $35-37^{\circ} \mathrm{C}$ & $4.200 \mathbf{a}$ & $59.870 \mathbf{b}$ & $1.540 \mathrm{abc}$ & $9.560 \mathrm{efg}$ & $20.750 \mathbf{a}$ & $3.050 \mathrm{e}$ & $5.070 \mathbf{a}$ & 2.913 cde \\
\hline \multicolumn{3}{|c|}{ SEM } & 0.017 & 0.260 & 0.024 & 0.347 & 0.561 & 0.133 & 0.345 & 0.052 \\
\hline \multicolumn{11}{|l|}{$p$ values } \\
\hline \multicolumn{3}{|l|}{ Additive } & 0.000 & 0.003 & 0.749 & 0.157 & 0.801 & 0.000 & 0.000 & 0.000 \\
\hline \multicolumn{3}{|l|}{ Usage } & 0.000 & 0.568 & 0.036 & 0.062 & 0.000 & 0.000 & 0.000 & 0.001 \\
\hline \multicolumn{3}{|c|}{ Temperature } & 0.000 & 0.910 & 0.004 & 0.000 & 0.000 & 0.000 & 0.000 & 0.000 \\
\hline \multicolumn{3}{|c|}{ Additive $x$ Usage } & 0.000 & 0.125 & 0.041 & 0.762 & 0.000 & 0.000 & 0.000 & 0.073 \\
\hline \multicolumn{3}{|c|}{ Additive $x$ Temperature } & 0.011 & 0.023 & 0.052 & 0.099 & 0.001 & 0.000 & 0.000 & 0.000 \\
\hline \multicolumn{3}{|c|}{ Usage $x$ Temperature } & 0.012 & 0.032 & 0.890 & 0.001 & 0.000 & 0.000 & 0.000 & 0.037 \\
\hline \multicolumn{3}{|c|}{ Additive $x$ Usage $x$ Temperature } & 0.003 & 0.002 & 0.000 & 0.007 & 0.000 & 0.021 & 0.000 & 0.000 \\
\hline
\end{tabular}

a-h: Values shown in different letters in the same column are statistically important $(p<0.05)$.

* Room conditions: $27-29^{\circ} \mathrm{C}, 48 \%$ Humidity; Incubator conditions: $35-37^{\circ} \mathrm{C}, 26 \%$ Humidity.

AV: Apple vinegar; SDA: Sodium diacetate; SEM: Standard error of means; DM: Dry matter; NH3-N: Ammonianitrogen, LA: Lactic acid; WSC: Water-soluble carbohydrate; LAB: Lactic acid bacteria. 
Table 3. Effects of additives and storage conditions on fourth day of aerobic stability of high moisture maize silage

\begin{tabular}{|c|c|c|c|c|c|c|c|c|c|c|}
\hline Additive & $\begin{array}{c}\text { Usage } \\
\%\end{array}$ & $\begin{array}{c}\text { Storage } \\
\text { temperature* }\end{array}$ & $\mathrm{pH}$ & $\begin{array}{c}\mathrm{DM} \\
\%\end{array}$ & $\begin{array}{l}\mathrm{NH}_{3}-\mathrm{N} \\
\mathrm{g} / \mathrm{kg} \mathrm{DM}\end{array}$ & $\begin{array}{c}\text { LA } \\
\mathrm{g} / \mathrm{kg} \mathrm{DM}\end{array}$ & $\begin{array}{c}\text { WSC } \\
\text { g/kg DM }\end{array}$ & $\begin{array}{c}\text { LAB } \\
\log _{10} \mathrm{cfu} / \mathrm{g}\end{array}$ & $\begin{array}{c}\text { Yeast } \\
\log _{10} \quad \mathrm{cfu} / \mathrm{g}\end{array}$ & $\begin{array}{c}\text { Mould } \\
\log _{10} \mathrm{cfu} / \mathrm{g}\end{array}$ \\
\hline \multirow{6}{*}{$\mathrm{AV}$} & \multirow[t]{2}{*}{0} & $27-29^{\circ} \mathrm{C}$ & $4.100 \mathrm{~d}$ & $63.457 \mathrm{e}$ & $1.410 \mathrm{e}$ & $9.867 \mathrm{~d}$ & $9.550 \mathrm{e}$ & $4.400 \mathrm{c}$ & $4.743 \mathrm{de}$ & $2.850 \mathrm{a}$ \\
\hline & & $35-37^{\circ} \mathrm{C}$ & $4.150 \mathrm{~d}$ & $61.183 \mathrm{f}$ & $1.040 \mathrm{~g}$ & $11.737 \mathrm{c}$ & $8.000 \mathrm{~g}$ & $3.793 \mathrm{~d}$ & $6.143 \mathrm{a}$ & $0.000 \mathrm{c}$ \\
\hline & \multirow[t]{2}{*}{0.5} & $27-29^{\circ} \mathrm{C}$ & $4.350 \mathrm{~b}$ & $63.080 \mathrm{de}$ & $1.430 \mathrm{de}$ & $6.800 \mathrm{i}$ & $6.357 \mathrm{~h}$ & $5.313 \mathrm{a}$ & $5.167 \mathrm{c}$ & $2.350 \mathrm{~b}$ \\
\hline & & $35-37^{\circ} \mathrm{C}$ & $4.200 \mathrm{c}$ & $65.380 \mathrm{bc}$ & $1.267 \mathrm{f}$ & $9.250 \mathrm{e}$ & $8.900 \mathrm{f}$ & $4.800 \mathrm{~b}$ & $5.800 \mathrm{~b}$ & $0.000 \mathrm{c}$ \\
\hline & \multirow[t]{2}{*}{1.0} & $27-29^{\circ} \mathrm{C}$ & $4.100 \mathrm{~d}$ & $63.383 \mathrm{de}$ & $1.547 \mathrm{bc}$ & $9.227 \mathrm{e}$ & 18.767 a & $5.210 \mathrm{a}$ & $5.157 \mathrm{c}$ & $0.000 \mathrm{c}$ \\
\hline & & $35-37^{\circ} \mathrm{C}$ & $3.900 \mathrm{~g}$ & $65.457 \mathrm{bc}$ & $1.580 \mathrm{~b}$ & $7.710 \mathrm{~h}$ & $12.300 \mathrm{c}$ & $3.760 \mathrm{~d}$ & $3.950 \mathrm{f}$ & $0.000 \mathrm{c}$ \\
\hline \multirow{6}{*}{ SDA } & \multirow[t]{2}{*}{0} & $27-29^{\circ} \mathrm{C}$ & $4.650 \mathrm{a}$ & $62.853 \mathrm{de}$ & $1.357 \mathrm{e}$ & $8.477 \mathrm{f}$ & $4.807 \mathrm{i}$ & $2.813 \mathrm{e}$ & $3.047 \mathrm{~g}$ & $0.000 \mathrm{c}$ \\
\hline & & $35-37^{\circ} \mathrm{C}$ & $4.100 \mathrm{~d}$ & $67.137 \mathrm{a}$ & $1.387 \mathrm{e}$ & $12.417 \mathrm{~b}$ & $14.060 \mathrm{~b}$ & $2.947 \mathrm{e}$ & $4.700 \mathrm{de}$ & $0.000 \mathrm{c}$ \\
\hline & \multirow[t]{2}{*}{0.5} & $27-29^{\circ} \mathrm{C}$ & $3.950 \mathrm{f}$ & $63.907 \mathrm{~cd}$ & $1.540 \mathrm{bc}$ & 13.417 a & $14.197 \mathrm{~b}$ & $3.883 \mathrm{~d}$ & $4.987 \mathrm{~cd}$ & $0.000 \mathrm{c}$ \\
\hline & & $35-37^{\circ} \mathrm{C}$ & $4.000 \mathrm{f}$ & 62.050 ef & $1.727 \mathrm{a}$ & $8.687 \mathrm{f}$ & $10.910 \mathrm{~d}$ & $2.607 \mathrm{ef}$ & $2.700 \mathrm{~h}$ & $0.000 \mathrm{c}$ \\
\hline & \multirow[t]{2}{*}{1.0} & $27-29^{\circ} \mathrm{C}$ & $4.100 \mathrm{~d}$ & $63.733 \mathrm{~d}$ & $1.240 \mathrm{f}$ & $9.327 \mathrm{e}$ & $8.897 \mathrm{f}$ & $2.310 \mathrm{f}$ & $4.530 \mathrm{e}$ & $0.000 \mathrm{c}$ \\
\hline & & $35-37^{\circ} \mathrm{C}$ & $4.000 \mathrm{f}$ & $66.463 \mathrm{ab}$ & $1.490 \mathrm{~cd}$ & $8.037 \mathrm{~g}$ & $11.100 \mathrm{~d}$ & $2.680 \mathrm{e}$ & $2.770 \mathrm{~h}$ & $0.000 \mathrm{c}$ \\
\hline \multicolumn{3}{|c|}{ SEM } & 0.033 & 0.311 & 0.030 & 0.322 & 0.619 & 0.172 & 0.186 & 0.165 \\
\hline \multicolumn{11}{|l|}{$p$ values } \\
\hline \multicolumn{3}{|l|}{ Additive } & 1.000 & 0.025 & 0.000 & 0.000 & 0.884 & 0.000 & 0.000 & 0.000 \\
\hline \multicolumn{3}{|c|}{ Usage } & 0.000 & 0.005 & 0.000 & 0.000 & 0.000 & 0.000 & 0.000 & 0.000 \\
\hline \multicolumn{3}{|c|}{ Temperature } & 0.000 & 0.000 & 0.683 & 0.018 & 0.000 & 0.000 & 0.000 & 0.000 \\
\hline \multicolumn{3}{|c|}{ Additive $x$ Usage } & 0.000 & 0.000 & 0.000 & 0.000 & 0.000 & 0.000 & 0.000 & 0.000 \\
\hline \multicolumn{3}{|c|}{ Additive $\mathrm{x}$ Temperature } & 0.000 & 0.094 & 0.000 & 0.000 & 0.000 & 0.000 & 0.000 & 0.000 \\
\hline \multicolumn{3}{|c|}{ Usage x Temperature } & 0.000 & 0.018 & 0.000 & 0.000 & 0.000 & 0.002 & 0.000 & 0.000 \\
\hline \multicolumn{3}{|c|}{ Additive $\mathrm{x}$ Usage $\mathrm{x}$ Temperature } & 0.000 & 0.000 & 0.029 & 0.000 & 0.000 & 0.000 & 0.000 & 0.000 \\
\hline
\end{tabular}

a-h: Values shown in different letters in the same column are statistically important $(p<0.05)$.

* Room conditions: $27-29^{\circ} \mathrm{C}, 48 \%$ Humidity; Incubator conditions: $35-37^{\circ} \mathrm{C}, 26 \%$ Humidity.

AV: Apple vinegar; SDA: Sodium diacetate; SEM: Standard error of means; DM: Dry matter; NH3-N: Ammonianitrogen, LA: Lactic acid; WSC: Water-soluble carbohydrate; LAB: Lactic acid bacteria. 
Table 4. Effects of additives and storage conditions on seventh day of aerobic stability of high moisture maize silage

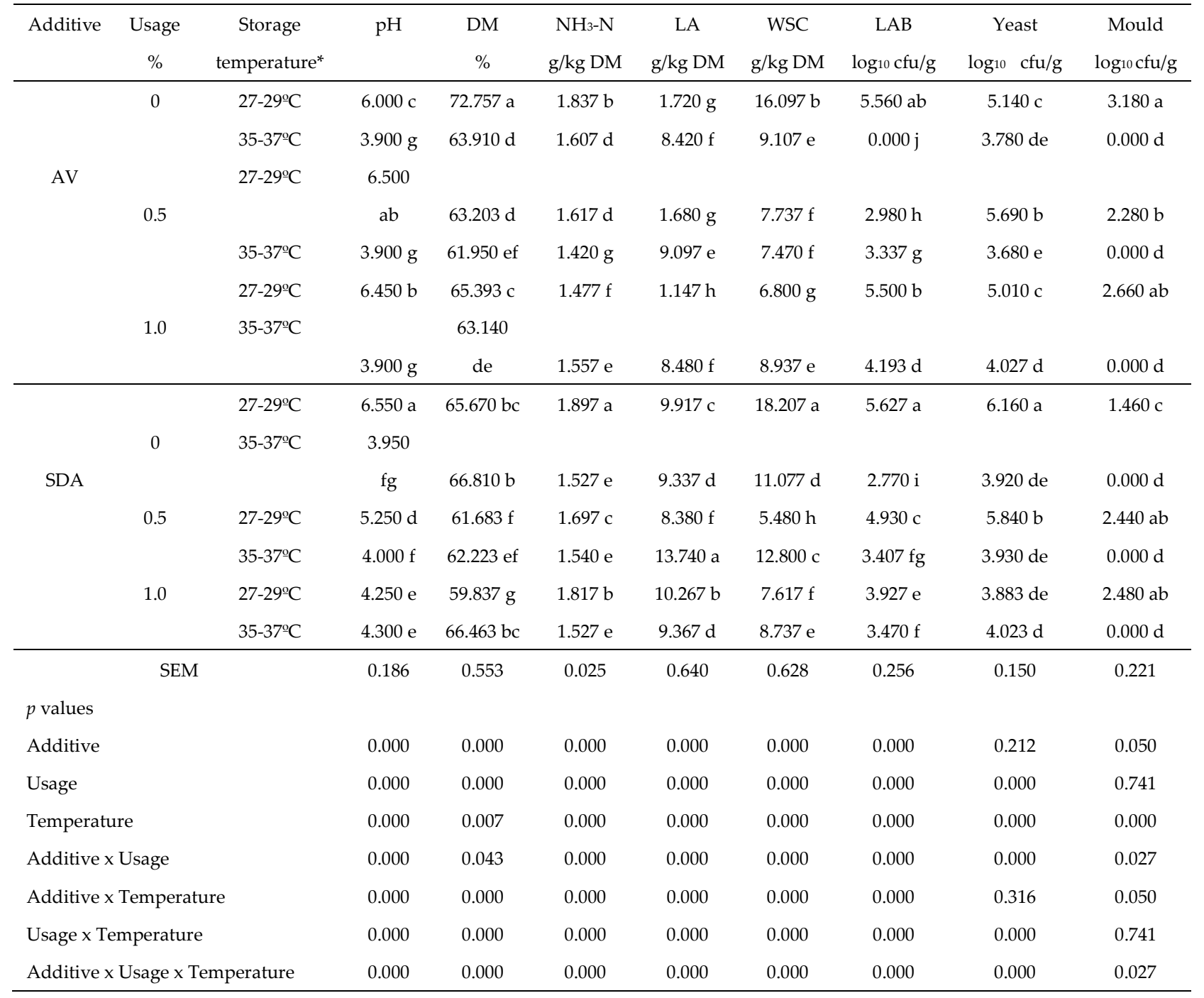

a-i: Values shown in different letters in the same column are statistically important $(p<0.05)$.

* Room conditions: $27-29^{\circ} \mathrm{C}, 48 \%$ Humidity; Incubator conditions: $35-37^{\circ} \mathrm{C}, 26 \%$ Humidity.

AV: Apple vinegar; SDA: Sodium diacetate; SEM: Standard error of means; DM: Dry matter; NH3-N: Ammonianitrogen, LA: Lactic acid; WSC: Water-soluble carbohydrate; LAB: Lactic acid bacteria. 
Table 5. Effects of additives and storage conditions on twelfth day of aerobic stability of high moisture maize silage

\begin{tabular}{|c|c|c|c|c|c|c|c|c|c|}
\hline Additive & $\begin{array}{c}\text { Usage } \\
\%\end{array}$ & $\begin{array}{c}\text { Storage } \\
\text { temperature* }\end{array}$ & $\mathrm{pH}$ & $\begin{array}{c}\mathrm{DM} \\
\%\end{array}$ & $\begin{array}{c}\mathrm{NH}_{3}-\mathrm{N} \\
\mathrm{g} / \mathrm{kg} \mathrm{DM}\end{array}$ & $\begin{array}{c}\text { LA } \\
\mathrm{g} / \mathrm{kg} \mathrm{DM}\end{array}$ & $\begin{array}{c}\text { WSC } \\
\mathrm{g} / \mathrm{kg} \mathrm{DM}\end{array}$ & $\begin{array}{c}\text { LAB } \\
\log _{10} \mathrm{cfu} / \mathrm{g}\end{array}$ & $\begin{array}{c}\text { Yeast } \\
\log _{10} \mathrm{cfu} / \mathrm{g}\end{array}$ \\
\hline \multirow{6}{*}{$\mathrm{AV}$} & \multirow[t]{2}{*}{0} & $27-29^{\circ} \mathrm{C}$ & $6.900 \mathrm{~b}$ & $71.577 \mathrm{a}$ & $2.693 \mathrm{a}$ & $0.757 \mathrm{e}$ & $16.517 \mathrm{~d}$ & $0.000 \mathrm{i}$ & $3.377 \mathrm{f}$ \\
\hline & & $35-37^{\circ} \mathrm{C}$ & $3.950 \mathrm{~d}$ & $67.417 \mathrm{abc}$ & 0.987 ef & $6.677 \mathrm{~d}$ & $55.230 \mathrm{~b}$ & $3.547 \mathrm{~b}$ & $5.670 \mathrm{~b}$ \\
\hline & \multirow[t]{2}{*}{0.5} & $27-29^{\circ} \mathrm{C}$ & $7.800 \mathrm{a}$ & $57.083 \mathrm{~d}$ & $2.600 \mathrm{a}$ & $0.370 \mathrm{e}$ & $17.827 \mathrm{~d}$ & $2.613 \mathrm{f}$ & $6.330 \mathrm{a}$ \\
\hline & & $35-37^{\circ} \mathrm{C}$ & $3.900 \mathrm{~d}$ & $66.283 \mathrm{bc}$ & $1.323 \mathrm{~d}$ & $9.750 \mathrm{~b}$ & $9.100 \mathrm{e}$ & $2.840 \mathrm{e}$ & $4.280 \mathrm{~cd}$ \\
\hline & \multirow[t]{2}{*}{1.0} & $27-29^{\circ} \mathrm{C}$ & $7.450 \mathrm{ab}$ & $60.637 \mathrm{~d}$ & $2.883 \mathrm{a}$ & 0.303 e & $18.177 \mathrm{~d}$ & $2.483 \mathrm{f}$ & $6.100 \mathrm{a}$ \\
\hline & & $35-37^{\circ} \mathrm{C}$ & $3.900 \mathrm{~d}$ & $69.970 \mathrm{ab}$ & $1.237 \mathrm{de}$ & $11.407 \mathrm{a}$ & $67.757 \mathrm{a}$ & $3.477 \mathrm{~b}$ & $4.390 \mathrm{~cd}$ \\
\hline \multirow{6}{*}{ SDA } & \multirow[t]{2}{*}{0} & $27-29^{\circ} \mathrm{C}$ & $6.950 \mathrm{~b}$ & $70.547 \mathrm{ab}$ & $2.807 \mathrm{a}$ & $1.060 \mathrm{e}$ & 7.747 e & $2.103 \mathrm{~h}$ & $6.367 \mathrm{a}$ \\
\hline & & $35-37^{\circ} \mathrm{C}$ & $3.900 \mathrm{~d}$ & $66.610 \mathrm{bc}$ & $1.363 \mathrm{~cd}$ & $7.930 \mathrm{c}$ & $46.140 \mathrm{c}$ & $3.297 \mathrm{~cd}$ & $3.797 \mathrm{e}$ \\
\hline & \multirow[t]{2}{*}{0.5} & $27-29^{\circ} \mathrm{C}$ & $7.200 \mathrm{ab}$ & $67.990 \mathrm{abc}$ & $2.250 \mathrm{~b}$ & 0.837 e & $15.760 \mathrm{~d}$ & $3.410 \mathrm{bc}$ & $3.710 \mathrm{e}$ \\
\hline & & $35-37^{\circ} \mathrm{C}$ & $3.900 \mathrm{~d}$ & $66.907 \mathrm{bc}$ & $1.433 \mathrm{~cd}$ & $6.520 \mathrm{~d}$ & $68.083 \mathrm{a}$ & $4.550 \mathrm{a}$ & $4.320 \mathrm{~cd}$ \\
\hline & \multirow[t]{2}{*}{1.0} & $27-29^{\circ} \mathrm{C}$ & $6.200 \mathrm{c}$ & $65.157 \mathrm{c}$ & $0.890 \mathrm{f}$ & $9.020 \mathrm{~b}$ & $19.190 \mathrm{~d}$ & $2.273 \mathrm{~g}$ & $4.607 \mathrm{c}$ \\
\hline & & $35-37^{\circ} \mathrm{C}$ & $4.050 \mathrm{~d}$ & $65.157 \mathrm{c}$ & $1.677 \mathrm{c}$ & $6.840 \mathrm{~d}$ & $55.610 \mathrm{~b}$ & $3.240 \mathrm{~d}$ & $4.247 \mathrm{~d}$ \\
\hline & \multicolumn{2}{|c|}{ SEM } & 0.278 & 0.732 & 0.124 & 0.679 & 3.800 & 0.180 & 0.174 \\
\hline \multicolumn{10}{|l|}{$p$ values } \\
\hline \multicolumn{3}{|l|}{ Additive } & 0.041 & 0.050 & 0.002 & 0.012 & 0.000 & 0.000 & 0.000 \\
\hline \multicolumn{3}{|l|}{ Usage } & 0.138 & 0.000 & 0.002 & 0.000 & 0.000 & 0.000 & 0.063 \\
\hline \multicolumn{3}{|c|}{ Temperature } & 0.000 & 0.051 & 0.000 & 0.000 & 0.000 & 0.000 & 0.000 \\
\hline \multicolumn{3}{|c|}{ Additive $x$ Usage } & 0.249 & 0.003 & 0.000 & 0.000 & 0.000 & 0.000 & 0.000 \\
\hline \multicolumn{3}{|c|}{ Additive $x$ Temperature } & 0.023 & 0.000 & 0.000 & 0.000 & 0.000 & 0.000 & 0.029 \\
\hline \multicolumn{3}{|c|}{ Usage $\mathrm{x}$ Temperature } & 0.065 & 0.000 & 0.000 & 0.000 & 0.000 & 0.000 & 0.000 \\
\hline \multicolumn{3}{|c|}{ Additive $x$ Usage $x$ Temperature } & 0.085 & 0.017 & 0.000 & 0.000 & 0.000 & 0.000 & 0.000 \\
\hline
\end{tabular}

a-g: Values shown in different letters in the same column are statistically important $(p<0.05)$.

* Room conditions: $27-29^{\circ} \mathrm{C}, 48 \%$ Humidity; Incubator conditions: $35-37^{\circ} \mathrm{C}, 26 \%$ Humidity.

AV: Apple vinegar; SDA: Sodium diacetate; SEM: Standard error of means; DM: Dry matter; NH3-N: Ammonianitrogen, LA: Lactic acid; WSC: Water-soluble carbohydrate; LAB: Lactic acid bacteria. 
Table 6. Thermal camera imaging results of aerobic stability on day 2 (Ambient temperature $=22^{\circ} \mathrm{C}$ )

\begin{tabular}{|c|c|c|c|c|c|c|c|}
\hline \multirow{2}{*}{$\begin{array}{l}\text { Aerobic } \\
\text { stability }\end{array}$} & \multirow[b]{2}{*}{ Additive } & \multirow[b]{2}{*}{$\%$} & \multirow{2}{*}{$\begin{array}{c}\text { Storage } \\
\text { Temperature* }\end{array}$} & \multicolumn{4}{|c|}{ Thermal Camera Imaging Measurements, ${ }^{\circ} \mathrm{C}$} \\
\hline & & & & Mean & Min & Max & Std. Dev. \\
\hline Day 0 & - & - & - & 30.62 & 26.75 & 33.91 & 0.94 \\
\hline \multirow{12}{*}{ Day 2} & \multirow{6}{*}{$\mathrm{AV}$} & \multirow[t]{2}{*}{0} & $27.370^{\circ} \mathrm{C}$ & $27.280 \mathrm{de}$ & $25.280 \mathbf{b}$ & $29.845 \mathrm{~d}$ & $0.420 \mathrm{c}$ \\
\hline & & & $36.187^{\circ} \mathrm{C}$ & $33.945 \mathbf{a b}$ & $28.345 \mathbf{a}$ & $36.330 \mathbf{a b}$ & $1.205 \mathbf{a}$ \\
\hline & & 0.5 & $27.370^{\circ} \mathrm{C}$ & 26.945 de & $24.595 \mathrm{~b}$ & $29.515 \mathrm{~d}$ & $0.490 \mathrm{c}$ \\
\hline & & & $36.187^{\circ} \mathrm{C}$ & $34.360 \mathbf{a}$ & $27.935 \mathbf{a}$ & $36.925 \mathbf{a}$ & $1.225 \mathbf{a}$ \\
\hline & & \multirow[t]{2}{*}{1.0} & $27.370^{\circ} \mathrm{C}$ & 26.865 de & $24.720 \mathrm{~b}$ & $29.640 \mathrm{~d}$ & $0.475 \mathrm{c}$ \\
\hline & & & $36.187^{\circ} \mathrm{C}$ & $33.740 \mathrm{ab}$ & $28.220 \mathrm{a}$ & $36.530 \mathrm{ab}$ & $1.225 \mathbf{a}$ \\
\hline & \multirow{6}{*}{ SDA } & \multirow[t]{2}{*}{0} & $27.370^{\circ} \mathrm{C}$ & $27.435 \mathrm{~d}$ & $25.610 \mathbf{b}$ & $29.375 \mathrm{~d}$ & $0.435 \mathrm{c}$ \\
\hline & & & $36.187^{\circ} \mathrm{C}$ & $33.555 \mathrm{ab}$ & $28.750 \mathbf{a}$ & $36.595 \mathbf{a b}$ & $1.225 \mathrm{a}$ \\
\hline & & \multirow[t]{2}{*}{0.5} & $27.370^{\circ} \mathrm{C}$ & 27.110 de & $25.530 \mathbf{b}$ & $29.280 \mathrm{~d}$ & $0.450 \mathrm{c}$ \\
\hline & & & $36.187^{\circ} \mathrm{C}$ & $33.100 \mathrm{bc}$ & $28.280 \mathrm{a}$ & $35.580 \mathrm{bc}$ & $1.070 \mathrm{ab}$ \\
\hline & & \multirow[t]{2}{*}{1.0} & $27.370^{\circ} \mathrm{C}$ & $26.430 \mathrm{e}$ & $24.690 \mathbf{b}$ & $29.330 \mathrm{~d}$ & $0.490 \mathrm{c}$ \\
\hline & & & $36.187^{\circ} \mathrm{C}$ & $32.420 \mathrm{c}$ & $27.955 \mathbf{a}$ & $34.985 \mathrm{c}$ & $0.940 \mathbf{b}$ \\
\hline SEM & & & & 0.689 & 0.358 & 0.705 & 0.075 \\
\hline \multicolumn{8}{|l|}{$p$ values } \\
\hline Additive & & & & 0.007 & 0.378 & 0.005 & 0.080 \\
\hline Usage & & & & 0.010 & 0.313 & 0.206 & 0.650 \\
\hline \multicolumn{4}{|c|}{ Temperature } & 0.000 & 0.000 & 0.000 & 0.000 \\
\hline \multicolumn{4}{|c|}{ Additive $x$ Usage } & 0.188 & 0.594 & 0.172 & 0.263 \\
\hline \multicolumn{4}{|c|}{ Additive $x$ Temperature } & 0.011 & 0.697 & 0.158 & 0.093 \\
\hline \multicolumn{4}{|c|}{ Usage $x$ Temperature } & 0.694 & 0.896 & 0.340 & 0.140 \\
\hline \multicolumn{4}{|c|}{ Additive $x$ Usage $x$ Temperature } & 0.538 & 0.911 & 0.077 & 0.291 \\
\hline
\end{tabular}

a-e: Values shown in different letters in the same column are statistically important $(p<0.05)$.

* Storage temperatures were recorded by data logger on day 2, while thermal camera images were taken. AV: Apple vinegar; SDA: Sodium diacetate; Std. Dev.: Standard deviation; SEM: Standard Error of Means 
Table 7. Thermal camera imaging results of aerobic stability on day 4 (Ambient temperature $=22^{\circ} \mathrm{C}$ )

\begin{tabular}{|c|c|c|c|c|c|c|c|}
\hline \multirow{2}{*}{$\begin{array}{l}\text { Aerobic } \\
\text { stability }\end{array}$} & \multirow[b]{2}{*}{ Additive } & \multirow[b]{2}{*}{$\%$} & \multirow{2}{*}{$\begin{array}{c}\text { Storage } \\
\text { Temperature* }\end{array}$} & \multicolumn{4}{|c|}{ Thermal Camera Imaging Measurements, ${ }^{\circ} \mathrm{C}$} \\
\hline & & & & Mean & Min & Max & Std. Dev. \\
\hline Day 0 & - & - & - & 30.62 & 26.75 & 33.91 & 0.94 \\
\hline \multirow{12}{*}{ Day 4} & \multirow{6}{*}{$\mathrm{AV}$} & \multirow[t]{2}{*}{0} & $27.468^{\circ} \mathrm{C}$ & $29.530 \mathrm{bc}$ & $27.470 \mathrm{~cd}$ & $31.000 \mathrm{c}$ & $0.365 \mathrm{~d}$ \\
\hline & & & $35.222^{\circ} \mathrm{C}$ & 33.575 a & 29.345 a & 35.655 a & $1.115 \mathbf{a}$ \\
\hline & & \multirow[t]{2}{*}{0.5} & $27.468^{\circ} \mathrm{C}$ & 29.535 bc & $27.925 \mathrm{~cd}$ & $31.250 \mathrm{c}$ & $0.380 \mathrm{~d}$ \\
\hline & & & $35.222^{\circ} \mathrm{C}$ & $33.515 \mathbf{a}$ & $29.565 \mathbf{a}$ & $35.390 \mathbf{a b}$ & $0.940 \mathbf{b}$ \\
\hline & & \multirow[t]{2}{*}{1.0} & $27.468^{\circ} \mathrm{C}$ & $29.090 \mathrm{~cd}$ & $27.265 \mathrm{~cd}$ & 30.955 c & $0.415 \mathrm{~d}$ \\
\hline & & & $35.222^{\circ} \mathrm{C}$ & $33.055 \mathbf{a}$ & $28.170 \mathrm{bc}$ & $35.265 \mathrm{ab}$ & $1.050 \mathrm{ab}$ \\
\hline & \multirow{6}{*}{ SDA } & \multirow[t]{2}{*}{0} & $27.468^{\circ} \mathrm{C}$ & $29.995 \mathbf{b}$ & $27.375 \mathrm{~cd}$ & $31.300 \mathrm{c}$ & $0.490 \mathrm{~d}$ \\
\hline & & & $35.222^{\circ} \mathrm{C}$ & $33.525 \mathbf{a}$ & $28.955 \mathrm{ab}$ & $35.450 \mathrm{ab}$ & $0.965 \mathbf{b}$ \\
\hline & & \multirow[t]{2}{*}{0.5} & $27.468^{\circ} \mathrm{C}$ & $28.775 \mathrm{~cd}$ & $27.345 \mathrm{~cd}$ & $31.000 \mathrm{c}$ & $0.475 \mathrm{~d}$ \\
\hline & & & $35.222^{\circ} \mathrm{C}$ & 32.745 a & 29.185 a & $34.660 \mathrm{~b}$ & 0.785 c \\
\hline & & \multirow[t]{2}{*}{1.0} & $27.468^{\circ} \mathrm{C}$ & $28.425 \mathrm{~d}$ & $27.060 \mathrm{~d}$ & $30.595 \mathrm{c}$ & $0.420 \mathrm{~d}$ \\
\hline & & & $35.222^{\circ} \mathrm{C}$ & $32.705 \mathbf{a}$ & 29.110 a & $34.595 \mathrm{~b}$ & $0.700 \mathrm{c}$ \\
\hline \multicolumn{4}{|l|}{ SEM } & 0.427 & 0.197 & 0.442 & 0.058 \\
\hline \multicolumn{8}{|l|}{$p$ values } \\
\hline \multicolumn{4}{|l|}{ Additive } & 0.042 & 0.479 & 0.078 & 0.018 \\
\hline \multicolumn{4}{|l|}{ Usage } & 0.003 & 0.030 & 0.086 & 0.026 \\
\hline \multicolumn{4}{|c|}{ Temperature } & 0.000 & 0.000 & 0.000 & 0.000 \\
\hline \multicolumn{4}{|c|}{ Additive $x$ Usage } & 0.064 & 0.131 & 0.328 & 0.055 \\
\hline \multicolumn{4}{|c|}{ Additive $\mathrm{x}$ Temperature } & 0.826 & 0.302 & 0.218 & 0.000 \\
\hline \multicolumn{4}{|c|}{ Usage $x$ Temperature } & 0.688 & 0.762 & 0.487 & 0.034 \\
\hline \multicolumn{4}{|c|}{ Additive $x$ Usage $x$ Temperature } & 0.565 & 0.224 & 0.967 & 0.702 \\
\hline
\end{tabular}

a-d: Values shown in different letters in the same column are statistically important $(p<0.05)$.

* Storage temperatures were recorded by data logger on day 4 , while thermal camera images were taken. AV: Apple vinegar; SDA: Sodium diacetate; Std. Dev.: Standard deviation; SEM: Standard Error of Means 
Table 8. Thermal camera imaging results of aerobic stability on day 7 (Ambient temperature $=22^{\circ} \mathrm{C}$ )

\begin{tabular}{|c|c|c|c|c|c|c|c|}
\hline \multirow{2}{*}{$\begin{array}{l}\text { Aerobic } \\
\text { stability }\end{array}$} & \multirow[b]{2}{*}{ Additive } & \multirow[b]{2}{*}{$\%$} & \multirow{2}{*}{$\begin{array}{c}\text { Storage } \\
\text { Temperature }^{*}\end{array}$} & \multicolumn{4}{|c|}{ Thermal Camera Imaging Measurements, ${ }^{\circ} \mathrm{C}$} \\
\hline & & & & Mean & Min & Max & Std. Dev. \\
\hline Day 0 & - & - & - & 30.62 & 26.75 & 33.91 & 0.94 \\
\hline \multirow{12}{*}{ Day 7} & & 0 & $28.060^{\circ} \mathrm{C}$ & 30.665 def & $27.780 \mathrm{bc}$ & 32.345 cde & 0.685 cde \\
\hline & & & $35.971^{\circ} \mathrm{C}$ & 34.290 a & 29.565 a & 36.265 a & $1.155 \mathrm{ab}$ \\
\hline & $\mathrm{AV}$ & 0.5 & $28.060^{\circ} \mathrm{C}$ & 31.535 cde & $27.875 \mathrm{bc}$ & $33.580 \mathrm{bcd}$ & $0.880 \mathrm{bcd}$ \\
\hline & & & $35.971^{\circ} \mathrm{C}$ & 33.800 a & $29.235 \mathbf{a b}$ & 35.890 a & $1.050 \mathrm{ab}$ \\
\hline & & 1.0 & $28.060^{\circ} \mathrm{C}$ & 30.520 def & $27.505 \mathrm{c}$ & 32.515 cde & $0.565 \mathrm{de}$ \\
\hline & & & $35.971^{\circ} \mathrm{C}$ & $32.670 \mathrm{abc}$ & $28.050 \mathrm{bc}$ & $35.110 \mathbf{a b}$ & $1.105 \mathrm{ab}$ \\
\hline & \multirow{6}{*}{ SDA } & 0 & $28.060^{\circ} \mathrm{C}$ & $29.265 \mathrm{f}$ & $27.250 \mathrm{c}$ & 31.375 e & $0.535 \mathbf{e}$ \\
\hline & & & $35.971^{\circ} \mathrm{C}$ & $32.895 \mathrm{abc}$ & $29.080 \mathrm{ab}$ & $35.015 \mathrm{ab}$ & $0.970 \mathrm{abc}$ \\
\hline & & 0.5 & $28.060^{\circ} \mathrm{C}$ & 31.925 bcd & $28.485 \mathrm{abc}$ & $34.440 \mathrm{abc}$ & $0.925 \mathrm{bc}$ \\
\hline & & & $35.971^{\circ} \mathrm{C}$ & $33.430 \mathrm{ab}$ & $28.440 \mathrm{abc}$ & 36.075 a & $1.295 \mathbf{a}$ \\
\hline & & 1.0 & $28.060^{\circ} \mathrm{C}$ & 30.115 ef & $27.425 \mathrm{c}$ & 32.205 de & 0.690 cde \\
\hline & & & $35.971^{\circ} \mathrm{C}$ & $33.280 \mathrm{abc}$ & $29.075 \mathbf{a b}$ & $35.450 \mathbf{a b}$ & $0.995 \mathbf{a b c}$ \\
\hline SEM & & & & 0.340 & 0.180 & 0.369 & 0.052 \\
\hline \multicolumn{8}{|l|}{$p$ values } \\
\hline Additive & & & & 0.178 & 0.867 & 0.622 & 0.933 \\
\hline Usage & & & & 0.032 & 0.262 & 0.033 & 0.023 \\
\hline \multicolumn{3}{|c|}{ Temperature } & & 0.000 & 0.000 & 0.000 & 0.000 \\
\hline \multicolumn{3}{|c|}{ Additive $x$ Usage } & & 0.113 & 0.306 & 0.235 & 0.131 \\
\hline \multicolumn{4}{|c|}{ Additive $x$ Temperature } & 0.887 & 0.867 & 0.895 & 0.844 \\
\hline \multicolumn{4}{|c|}{ Usage $x$ Temperature } & 0.098 & 0.204 & 0.189 & 0.416 \\
\hline \multicolumn{4}{|c|}{ Additive $x$ Usage $x$ Temperature } & 0.499 & 0.160 & 0.767 & 0.344 \\
\hline
\end{tabular}

a-f: Values shown in different letters in the same column are statistically important $(p<0.05)$.

* Storage temperatures were recorded by data logger on day 7, while thermal camera images were taken. AV: Apple vinegar; SDA: Sodium diacetate; Std. Dev.: Standard deviation; SEM: Standard Error of Means 
Table 9. Thermal camera imaging results of aerobic stability on day 12 (Ambient temperature $=22^{\circ} \mathrm{C}$ )

\begin{tabular}{|c|c|c|c|c|c|c|c|}
\hline \multirow{2}{*}{$\begin{array}{l}\text { Aerobic } \\
\text { stability }\end{array}$} & \multirow[b]{2}{*}{ Additive } & \multirow[b]{2}{*}{$\%$} & \multirow{2}{*}{$\begin{array}{c}\text { Storage } \\
\text { Temperature* }\end{array}$} & \multicolumn{4}{|c|}{ Thermal Camera Imaging Measurements, ${ }^{\circ} \mathrm{C}$} \\
\hline & & & & Mean & Min & Max & Std. Dev. \\
\hline Day 0 & - & - & - & 30.62 & 26.75 & 33.91 & 0.94 \\
\hline \multirow{12}{*}{ Day 12} & \multirow{6}{*}{$\mathrm{AV}$} & \multirow[t]{2}{*}{0} & $27.567^{\circ} \mathrm{C}$ & $28.770 \mathrm{c}$ & $26.840 \mathrm{bc}$ & $30.360 \mathrm{c}$ & $0.415 \mathrm{~d}$ \\
\hline & & & $36.295^{\circ} \mathrm{C}$ & $32.610 \mathbf{a}$ & $28.875 \mathbf{a}$ & $34.685 \mathbf{a}$ & $0.815 \mathbf{a b c}$ \\
\hline & & \multirow[t]{2}{*}{0.5} & $27.567^{\circ} \mathrm{C}$ & $27.645 \mathrm{c}$ & $25.925 \mathrm{c}$ & $29.720 \mathrm{c}$ & $0.470 \mathrm{~d}$ \\
\hline & & & $36.295^{\circ} \mathrm{C}$ & $33.310 \mathbf{a}$ & 29.190 a & $35.250 \mathbf{a}$ & $0.945 \mathbf{a}$ \\
\hline & & \multirow[t]{2}{*}{1.0} & $27.567^{\circ} \mathrm{C}$ & $27.710 \mathrm{c}$ & $26.170 \mathrm{bc}$ & $30.000 \mathrm{c}$ & $0.455 \mathrm{~d}$ \\
\hline & & & $36.295^{\circ} \mathrm{C}$ & $32.790 \mathbf{a}$ & $28.955 \mathbf{a}$ & $35.050 \mathbf{a}$ & $0.855 \mathrm{abc}$ \\
\hline & \multirow{6}{*}{ SDA } & \multirow[t]{2}{*}{0} & $27.567^{\circ} \mathrm{C}$ & $30.010 \mathrm{~b}$ & $26.125 \mathrm{bc}$ & $32.285 \mathbf{b}$ & $0.840 \mathrm{abc}$ \\
\hline & & & $36.295^{\circ} \mathrm{C}$ & $32.895 \mathbf{a}$ & 29.185 a & $35.565 \mathrm{a}$ & $0.925 \mathbf{a}$ \\
\hline & & \multirow[t]{2}{*}{0.5} & $27.567^{\circ} \mathrm{C}$ & $29.925 \mathbf{b}$ & 26.905 bc & $32.080 \mathrm{~b}$ & $0.695 \mathrm{bc}$ \\
\hline & & & $36.295^{\circ} \mathrm{C}$ & $32.810 \mathbf{a}$ & $28.920 \mathrm{a}$ & $34.940 \mathbf{a}$ & $0.890 \mathbf{a b}$ \\
\hline & & \multirow[t]{2}{*}{1.0} & $27.567^{\circ} \mathrm{C}$ & $30.260 \mathrm{~b}$ & $27.170 \mathrm{~b}$ & $32.045 \mathrm{~b}$ & $0.665 \mathrm{c}$ \\
\hline & & & $36.295^{\circ} \mathrm{C}$ & $33.325 \mathbf{a}$ & $29.880 \mathrm{a}$ & $35.315 \mathbf{a}$ & $0.830 \mathrm{abc}$ \\
\hline \multicolumn{4}{|l|}{ SEM } & 0.445 & 0.297 & 0.460 & 0.040 \\
\hline \multicolumn{8}{|l|}{$p$ values } \\
\hline \multicolumn{4}{|l|}{ Additive } & 0.000 & 0.086 & 0.000 & 0.001 \\
\hline \multicolumn{4}{|l|}{ Usage } & 0.844 & 0.394 & 0.705 & 0.458 \\
\hline \multicolumn{4}{|c|}{ Temperature } & 0.000 & 0.000 & 0.000 & 0.000 \\
\hline \multicolumn{4}{|c|}{ Additive $x$ Usage } & 0.304 & 0.095 & 0.777 & 0.095 \\
\hline \multicolumn{4}{|c|}{ Additive $x$ Temperature } & 0.001 & 0.805 & 0.001 & 0.002 \\
\hline \multicolumn{4}{|c|}{ Usage $x$ Temperature } & 0.219 & 0.919 & 0.724 & 0.574 \\
\hline \multicolumn{4}{|c|}{ Additive $x$ Usage $x$ Temperature } & 0.246 & 0.105 & 0.345 & 0.898 \\
\hline
\end{tabular}

a-d: Values shown in different letters in the same column are statistically important $(p<0.05)$.

* Storage temperatures were recorded by data logger on day 12, while thermal camera images were taken. AV: Apple vinegar; SDA: Sodium diacetate; Std. Dev.: Standard deviation; SEM: Standard Error of Means 


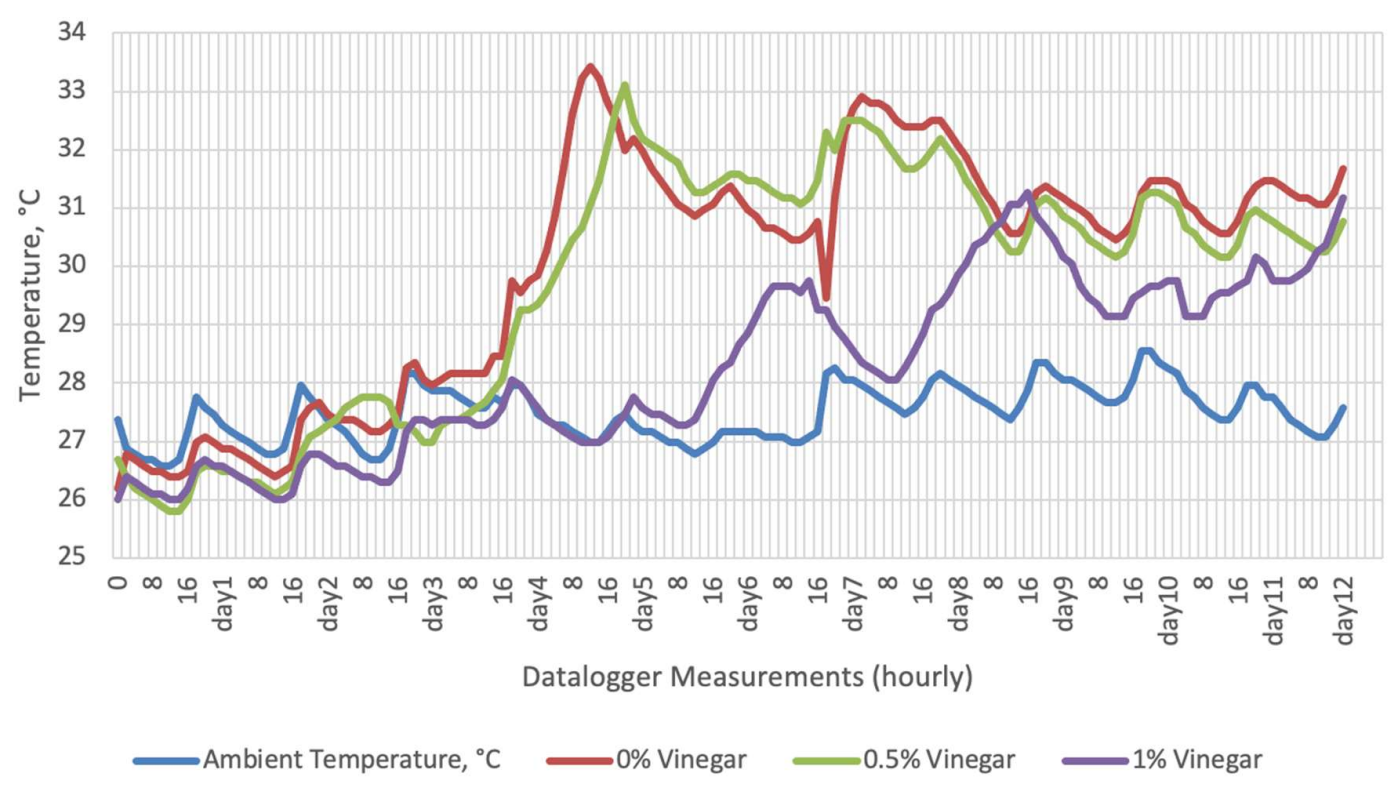

Figure 1. Temperature changes of apple vinegar supplemented groups stored at room conditions for 12 day.

* Ambient temperatures of room conditions: $27-29^{\circ} \mathrm{C}$ ( $48 \%$ Humidity).

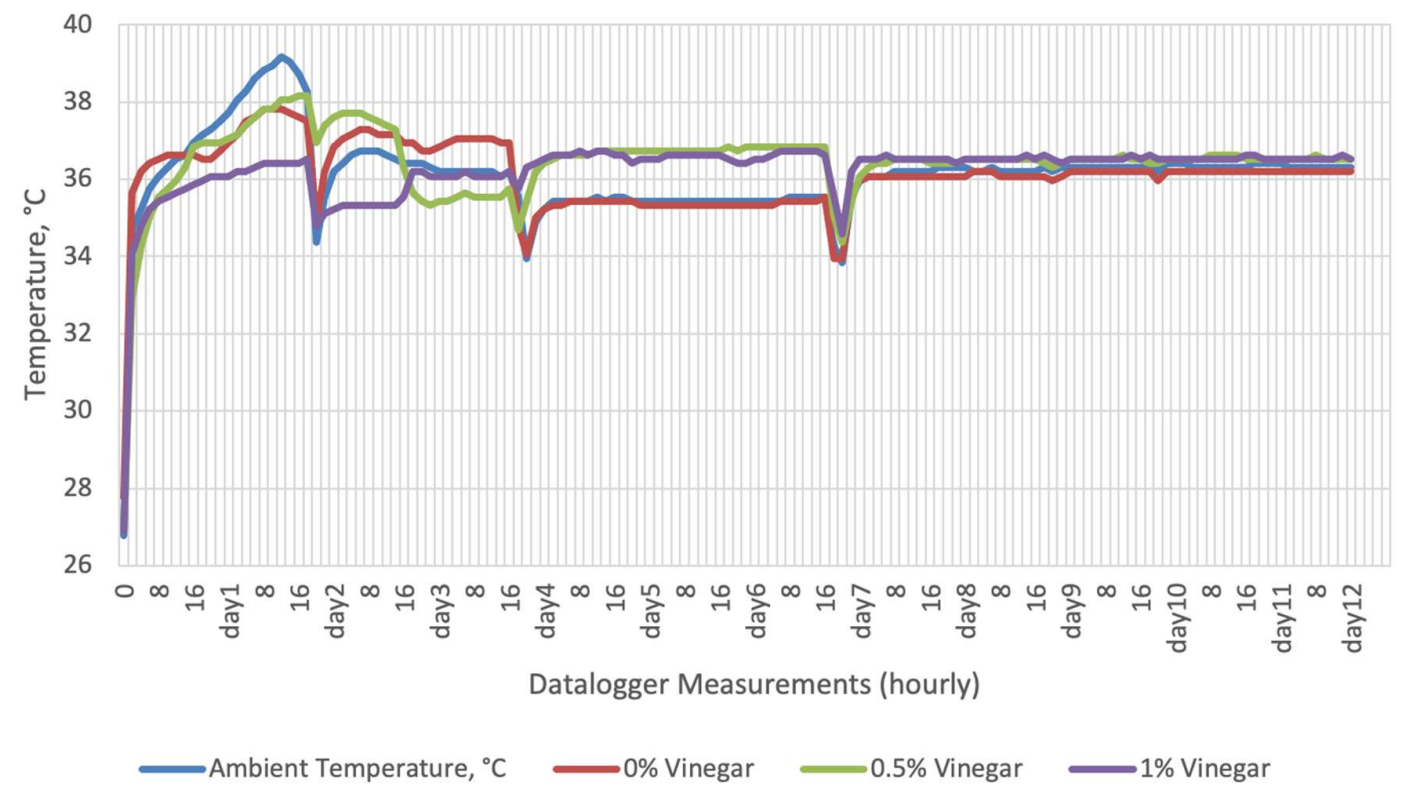

Figure 2. Temperature changes of apple vinegar supplemented groups stored at incubator conditions for 12 day.

${ }^{*}$ Ambient temperatures of incubator conditions: $35-37^{\circ} \mathrm{C}$ (26\% Humidity). 


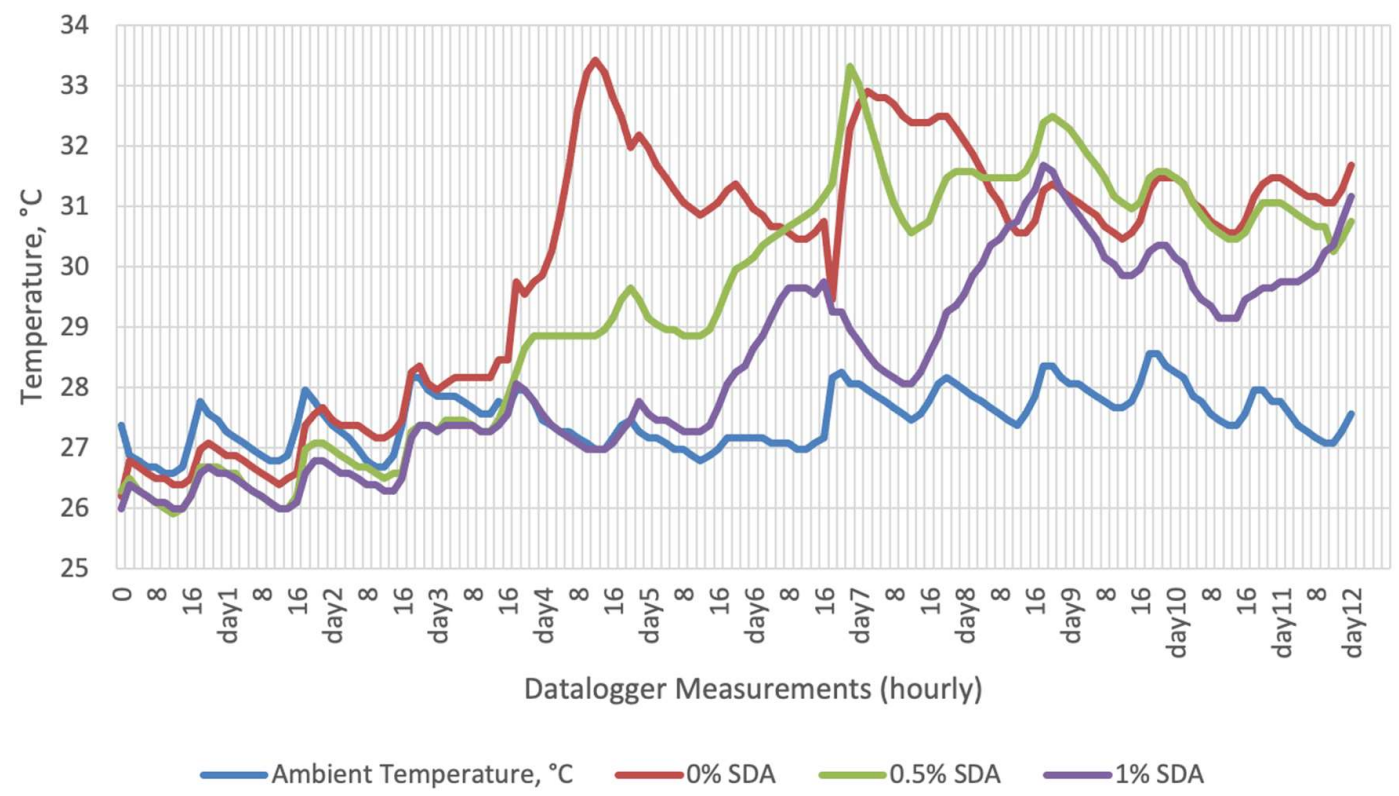

Figure 3. Temperature changes of SDA supplemented groups stored at room conditions for 12 day.

* Ambient temperatures of room conditions: $27-29^{\circ} \mathrm{C}(48 \%$ Humidity).

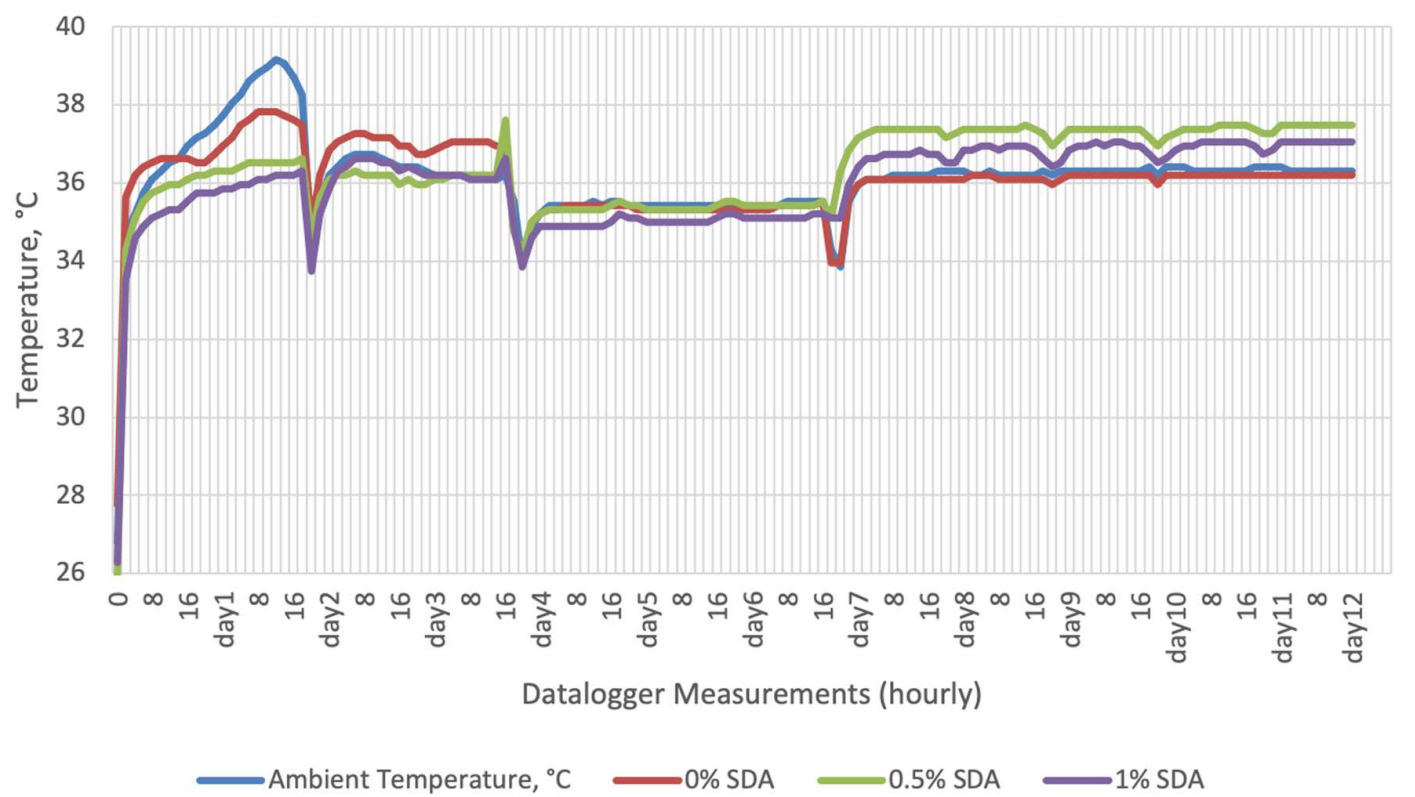

Figure 4. Temperature changes of SDA supplemented groups stored at incubator conditions for 12 day.

${ }^{*}$ Ambient temperatures of incubator conditions: $35-37^{\circ} \mathrm{C}$ (26\% Humidity). 
Day 0
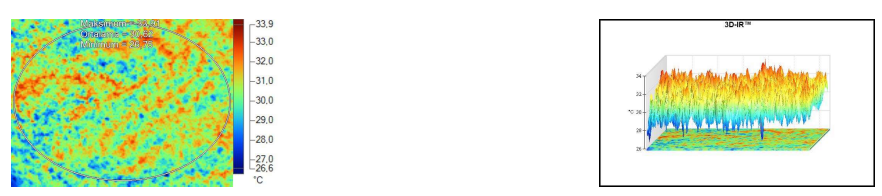

Storage Conditions

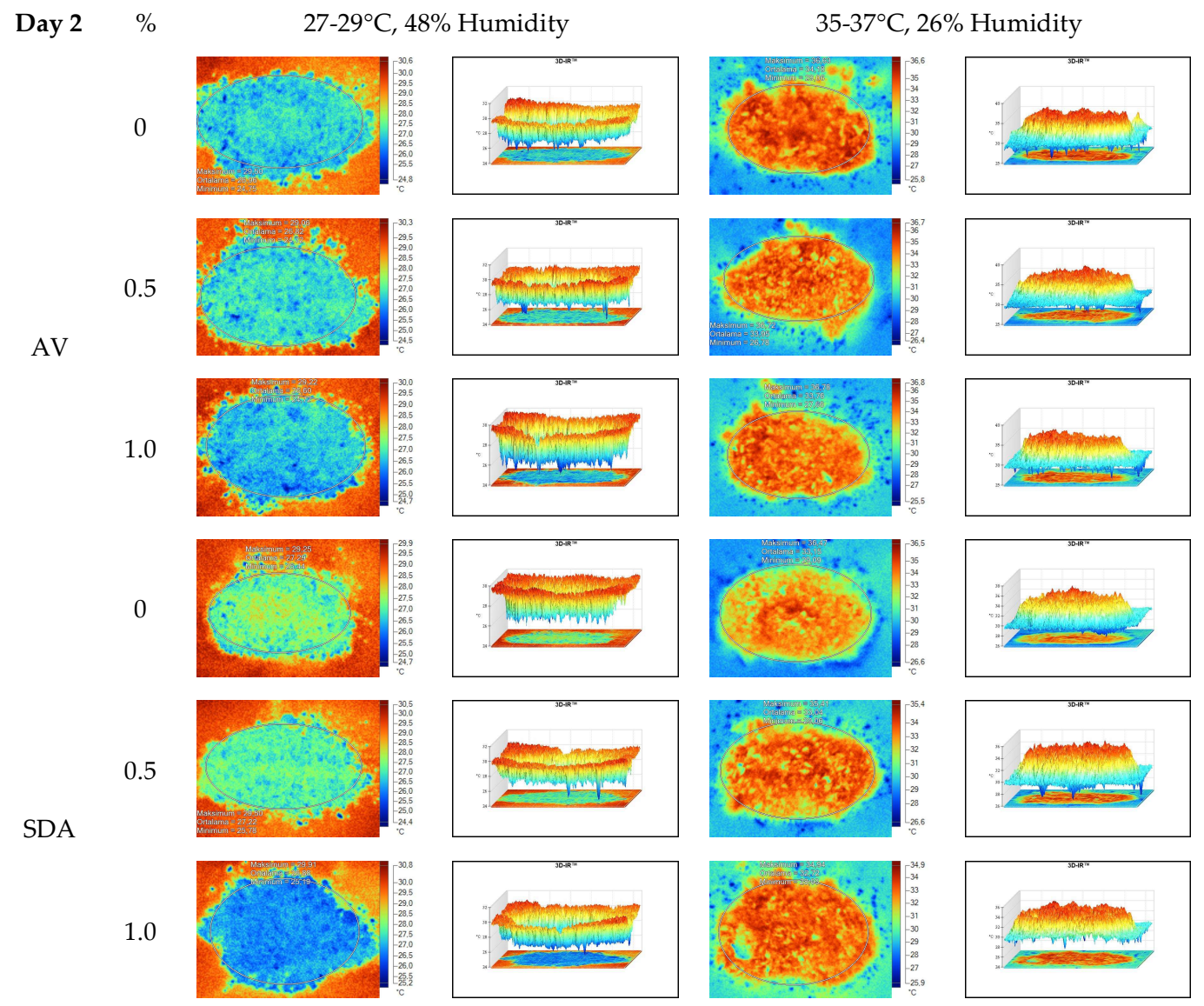

Figure 5. Thermal camera imaging samples of aerobic stability on day 2 (Ambient temperature $\left.=22^{\circ} \mathrm{C}\right)$. (AV: Apple vinegar; SDA: Sodium diacetate) 
Day 0
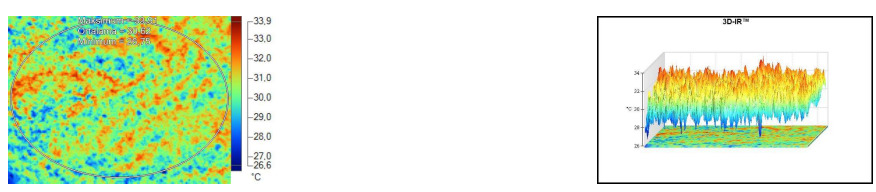

\section{Storage Conditions}

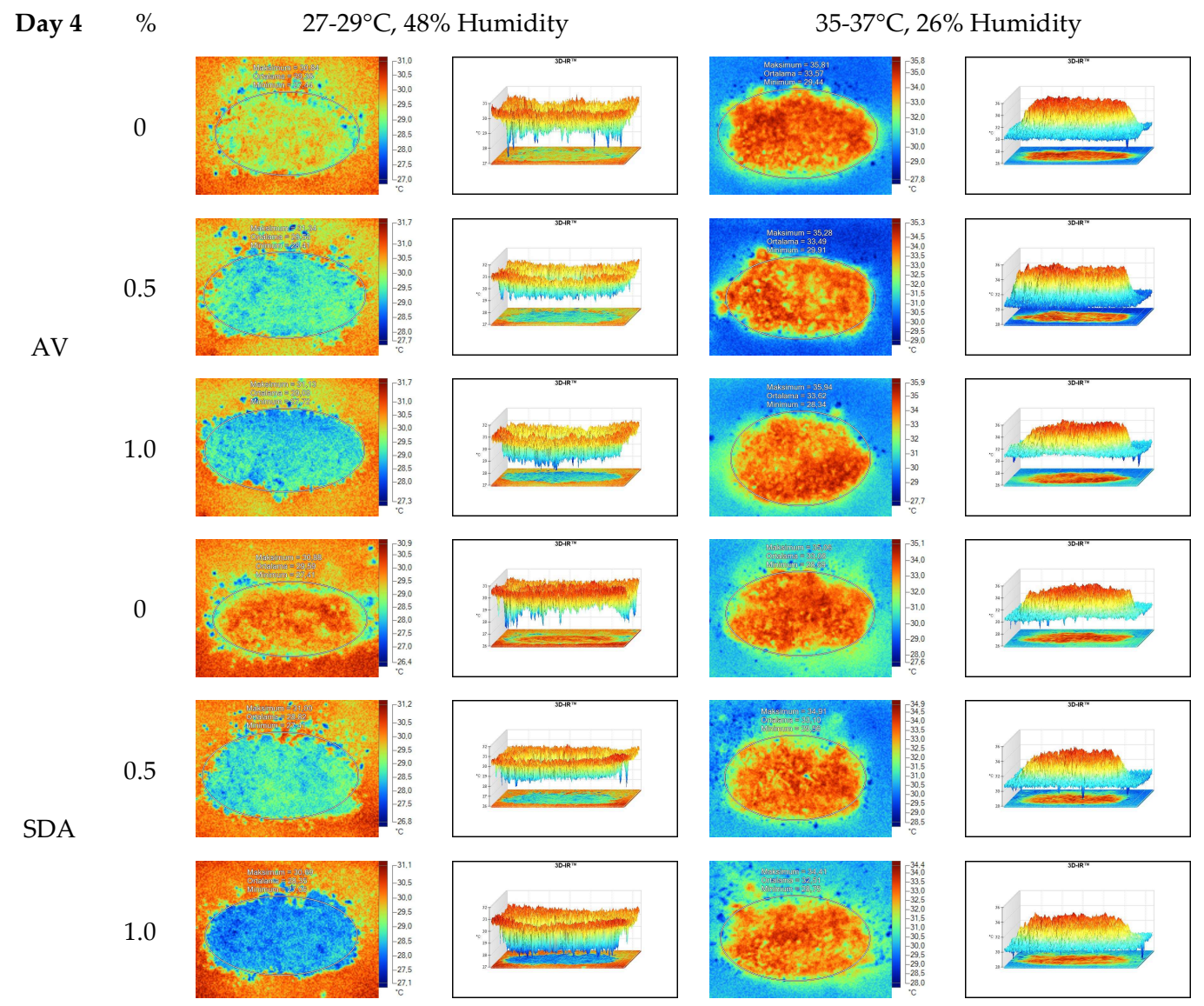

Figure 6. Thermal camera imaging samples of aerobic stability on day 4 (Ambient temperature $\left.=22^{\circ} \mathrm{C}\right)$. (AV: Apple vinegar; SDA: Sodium diacetate) 
Day 0
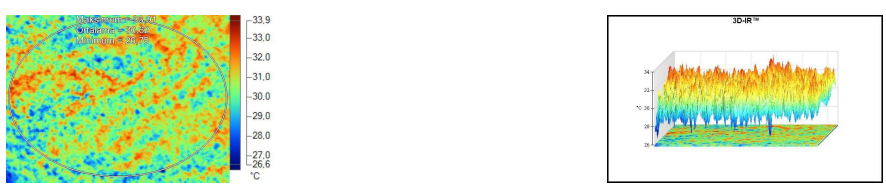

Storage Conditions

Day $7 \quad \% \quad 27-29^{\circ} \mathrm{C}, 48 \%$ Humidity

0

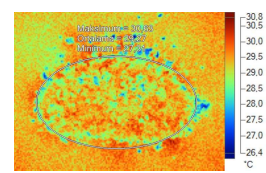

0.5

AV

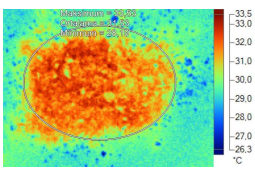

1.0

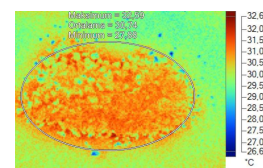

0

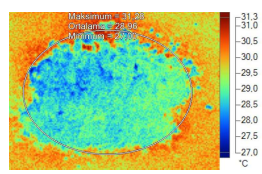

0.5

SDA
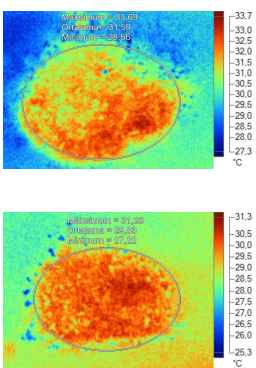
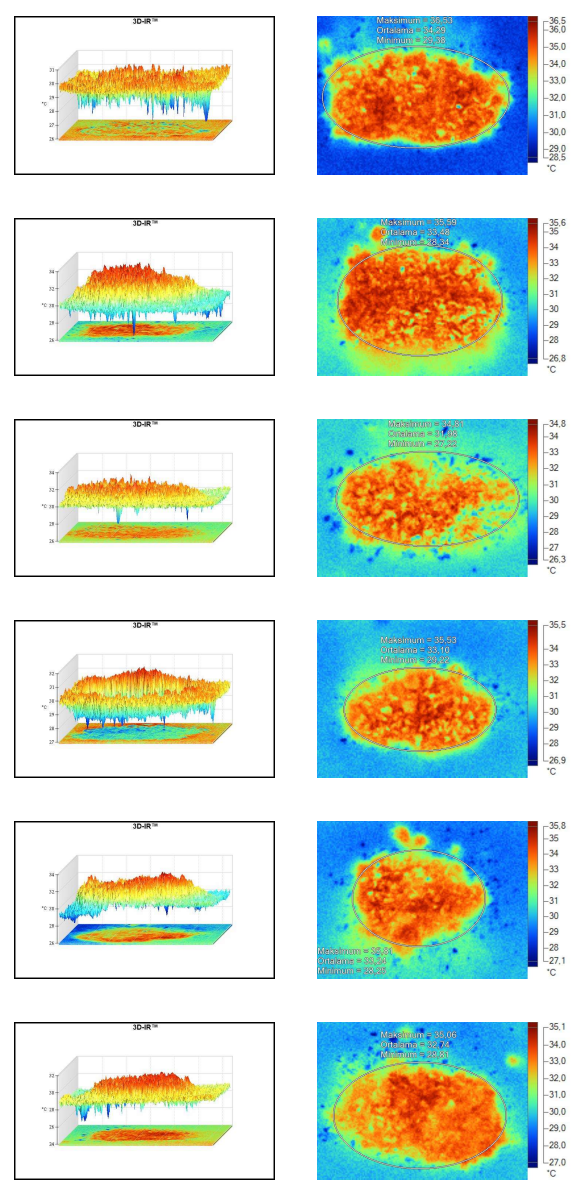

$35-37^{\circ} \mathrm{C}, 26 \%$ Humidity
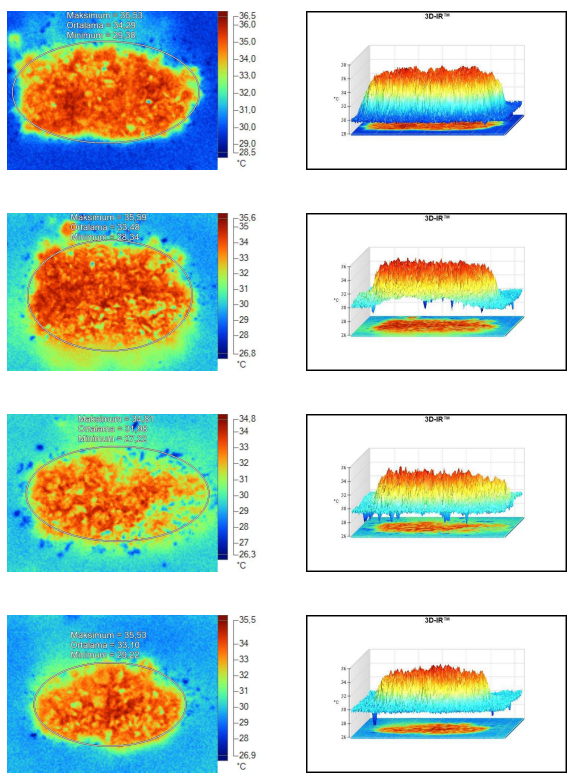

Figure 7. Thermal camera imaging samples of aerobic stability on day 7 (Ambient temperature $\left.=22^{\circ} \mathrm{C}\right)(\mathrm{AV}$ : Apple vinegar; SDA: Sodium diacetate) 
Day 0
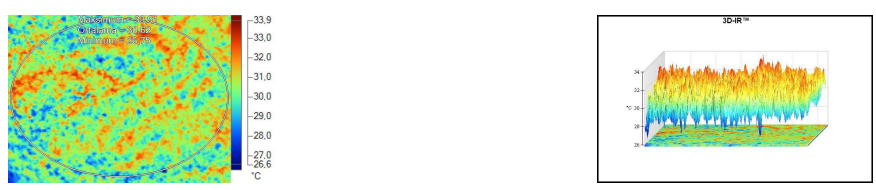

\section{Storage Conditions}

Day $12 \%$

0
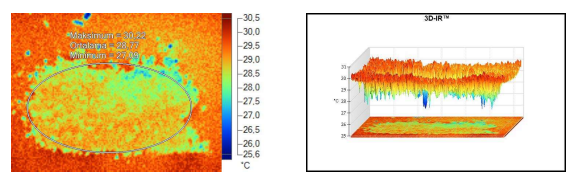

0.5

AV

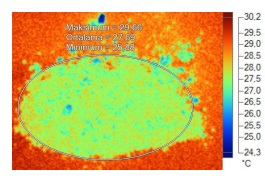

1.0
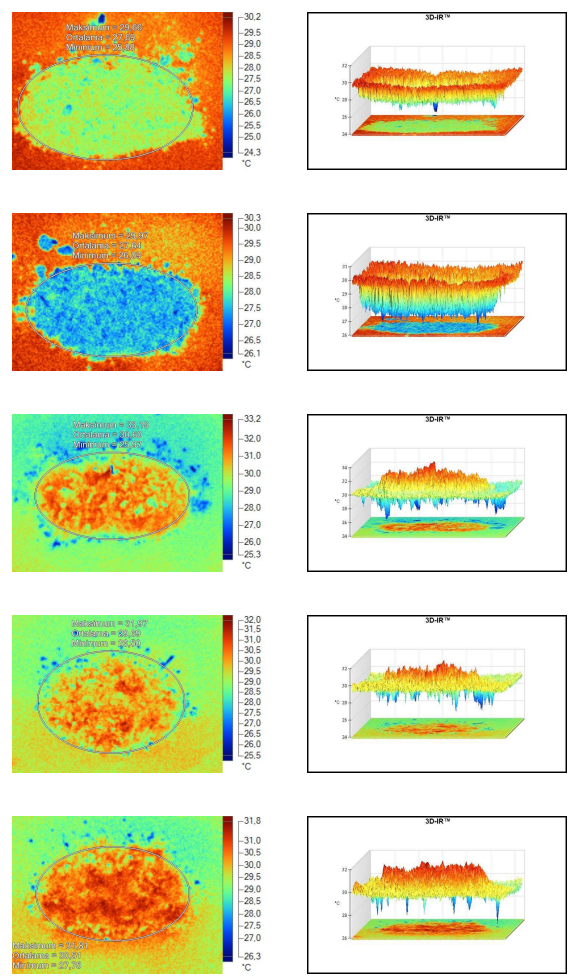
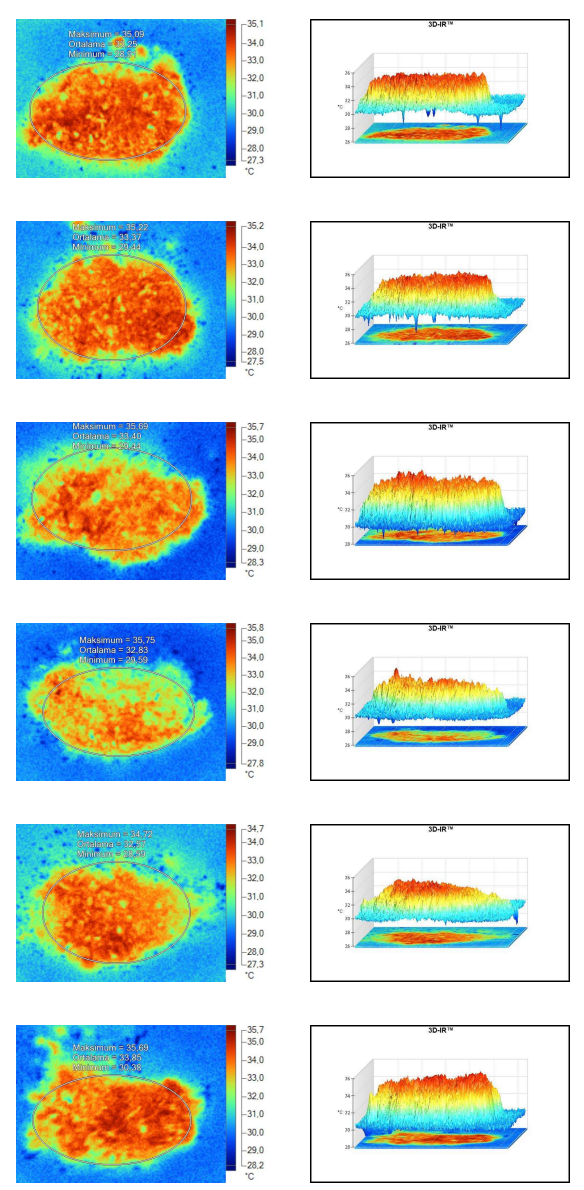

Figure 8. Thermal camera imaging samples of aerobic stability on day 12 (Ambient temperature $\left.=22^{\circ} \mathrm{C}\right)(\mathrm{AV}$ : Apple vinegar; SDA: Sodium diacetate) 